\title{
Temporal and spatial hydrogeochemical evolution and lead isotopic composition of a contaminated stream of Taxco, Guerrero, Mexico
}

\author{
Natasha Mylena Quevedo-Castañón', Oscar Talavera-Mendoza, ${ }^{1,2,}$, Sergio Adrián Salgado-Souto ${ }^{2}$, \\ Joaquin Ruiz ${ }^{3}$, Azucena Dótor-Almazán ${ }^{4}$, Alejandro Hermelindo Ramírez-Guzmán², \\ Laura Sampedro-Rosas ${ }^{1}$, José Luis Rosas-Acevedo ${ }^{1}$, and José Daniel Chávez-González ${ }^{5}$
}

\author{
${ }^{1}$ Doctorado en Ciencias Ambientales, Centro de Ciencias de Desarrollo Regional, \\ Universidad Autónoma de Guerrero, privada de Laurel No. 13, Col. El Roble, C.P. 39640, Acapulco, Gro., Mexico. \\ ${ }^{2}$ Escuela Superior de Ciencias de la Tierra, Universidad Autónoma de Guerrero, \\ Exhacienda San Juan Bautista s/n, Taxco el Viejo, Guerrero, 40323, Mexico. \\ ${ }^{3}$ Department of Geosciences, University of Arizona, 1040 East 4th Street, Tucson, Arizona 85721, USA \\ ${ }^{4}$ Instituto de Geofísica, Universidad Nacional Autónoma de México, Circuito de la Investigación s/n, \\ C.U., Coyoacán, 04510, Mexico City, Mexico. \\ ${ }^{5}$ CINVESTAV Campus Irapuato, Instituto Politécnico Nacional, \\ Km. 9.6 Libramiento Norte Carr. Irapuato-León, 36824, Irapuato, Guanajuato, Mexico. \\ *otalavera.uagro@gmail.com
}

\section{ABSTRACT}

Discharge of Acid Mine Drainage (AMD) produced within flooded mines is a major environmental issue in most polymetallic mining sites severely impacting nearby natural resources and producing a serious menace to the ecosystem and humans. The identification of both natural and anthropological factors influencing the bioavailability of toxic elements is relevant in revealing their behavior but also in the design of strategies for mitigating adverse effects to the environment. For these purposes, we carried out a spatial and seasonal hydrogeochemical (total and soluble contents) and a lead isotopic study of the AMD of the Xochula stream in the mining region of Taxco, Guerrero, in southern Mexico. The AMD is produced by the periodic discharge from the flooded Guerrero mine to the Xochula stream and is characterized by low to moderate $\mathrm{pH}$, high sulfate, and high total and soluble metal contents. The AMD shows significant spatial but smaller temporal variations. Flow of AMD through a culvert made of concrete produces the most important chemical changes recorded regardless of the time of year significantly decreasing the electrical conductance and the concentration of total and soluble potentially toxic elements. Distribution of metals and As between dissolved and particulate-bound species is $\mathrm{pH}$-controlled. Due to the short interaction time between the AMD and bedrock and the formation of coatings, lithology plays a minor role in neutralization, whereas mixing of AMD with freshwater is only significant in the less acidic segment of the stream. Neutralization of AMD entails a significant decrease of the concentration of both total and soluble metals and As and chemical speciation indicates that oxides, carbonates and sulfates are the reactive phases. The $\mathrm{Pb}$ isotopic composition reveals that metals derive from the Taxco ore deposit and that AMD is influenced by rocks of the Morelos and Taxco Schist formations.

Key words: acid rock drainage; Hydrochemistry; chemical speciation; lead isotopes.

\section{RESUMEN}

El drenaje ácido de mina (DAM) representa un serio problema ambiental en muchas regiones mineras ya que afecta a los recursos naturales, a los ecosistemas y al hombre. La identificación de los factores naturales y antropogénicos que afectan la biodisponibilidad de los elementos tóxicos es relevante para conocer su comportamiento en la naturaleza y para diseñar estrategias de mitigación. En este trabajo se realizó un estudio hidrogeoquímico espacio-temporal complementado con un estudio isotópico de plomo del DAM del Arroyo Xochula de la región minera de Taxco, Guerrero (parte sur de México). El DAM es producido por la descarga periódica de la Mina Guerrero al Arroyo Xochula y se caracteriza por valores bajos de $\mathrm{pH}$, altos contenidos de sulfatos y altos contenidos de metales totales $y$ solubles. Los resultados mostraron variaciones espaciales significativas y variaciones temporales menos evidentes. Su conducción a través de un tubo de concreto produce cambios importantes durante todo el año disminuyendo la conductividad eléctrica y la concentración de elementos tóxicos totales y solubles. La distribución de metales y As entre la fracción soluble y el particulado está controlada por el $p H$. Debido al elevado flujo del DAM y a la formación de costras de oxihidróxidos de Fe, la roca del sustrato juega un papel menor en la neutralización, mientras que su mezcla con agua de tributarios fue significativa en el segmento menos ácido del arroyo. Su neutralización provoca una reducción importante en las concentraciones totales y solubles de metales y As. La especiación química indicó que tanto los óxidos como los carbonatos y sulfatos son las fases reactivas que controlan su precipitación. La composición isotópica reveló que el $\mathrm{Pb}$ y los metales asociados derivan principalmente de la mineralización del distrito pero en algunos sitios, la influencia de las rocas de las formaciones Morelos y Esquisto Taxco es importante.

Palabras clave: drenaje ácido de mina; hidrogeoquímica; especiación química, isótopos de plomo.

Quevedo-Castañón, N.M., Talavera-Mendoza O., Salgado-Souto, S.A., Ruiz, J., Dótor-Almazán. A., Ramírez-Guzmán, A.H., Sampedro-Rosas, L., Rosas-Acevedo, J.L., Chávez-González, J.D., 2020, Temporal and spatial hydrogeochemical evolution and lead isotopic composition of a contaminated stream of Taxco, Guerrero, Mexico: Revista Mexicana de Ciencias Geológicas, v. 37, núm. 1, p. 64-79. 


\section{INTRODUCTION}

Acid Mine Drainage (AMD) is acidic water $(\mathrm{pH}<5.0)$ containing elevated concentrations of sulfate and toxic elements like $\mathrm{As}, \mathrm{Cd}, \mathrm{Pb}$, $\mathrm{Fe}, \mathrm{Cu}, \mathrm{Zn}$ and $\mathrm{Mn}$ formed by the interaction of sulfide-bearing rocks and mining wastes with atmospheric oxygen and water (e.g. Mukherjee, 2011). Due to its toxicity, the extraction of AMD produced within flooded mines and its discharge to neighboring streams and rivers represents an important source of pollution for surface water and aquifers by toxic elements and a serious menace to aquatic ecosystems (e.g. Winterbourn et al., 2000; DeNicol and Stapleton, 2002; Battaglia et al., 2005; Hogsden and Harding, 2012; Gray et al., 2016; Talukdar et al., 2017). If contaminated waters are further used for agricultural activities or as sources of domestic water, the disposal of acidic waters becomes an issue of public health concern (e.g. Johnson and Hallberg, 2005; Akcil and Koldas, 2006; Zhuang et al., 2009; Ngole-Jeme and Fantke, 2017). The interaction of acidic waters with bedrock and bottom sediments has been shown to be an efficient process to naturally increase $\mathrm{pH}$ and to reduce the metal load of AMD (e.g. Webb and Sasowsky, 1994; Skousen et al., 2017). Although the kinetics of the process is highly variable, acceptable remediation may occur far from the discharge point affecting aquatic ecosystems. Despite this, the monitoring of chemical changes of toxic elements in discharge streams has been a matter of great concern to environmentalists because it may provide helpful information on the geochemical processes immobilizing toxic elements during remediation of mining waters (e.g. Sánchez-España et al., 2006; Florence et al., 2016).

Taxco, Guerrero is in southern Mexico and is one of the oldest mining regions in America exploiting base $(\mathrm{Cu}-\mathrm{Pb}-\mathrm{Zn})$ and precious (Ag-Au) metals since the $15^{\text {th }}$ century. As a consequence, huge amounts of solid and liquid wastes have been discarded to the nearby environment and many studies have documented their impact on natural resources (e.g. Talavera et al., 2005, 2006, 2016), including plants (e.g. Gómez-Bernal et al., 2010; Ruiz-Huerta and Armienta-Hernández, 2012) and humans (e.g. Moreno et al., 2010; Vázquez-Bahena et al., 2017; Soto-Ríos et al., 2017). Even though tailings have the potential to generate acid drainage (e.g. Talavera et al., 2005; Romero et al., 2007), the high buffer capacity of bedrock prevents AMD from being a serious problem in the area (Romero et al., 2011). By contrast, the discharge of large volumes of acidic waters from flooded mines to streams and rivers has locally become an important environmental issue. The objective of this study was to evaluate the behavior of toxic elements in the AMD of the Xochula stream in the mining region of Taxco, Guerrero in southern Mexico during the interaction of acid waters with neutral waters, oxidized tailings and carbonate-rich bedrock. To reach this objective, we conducted a spatial and seasonal hydrogeochemical study of AMD determining both, soluble and total element contents. The later were further used to calculate the reactive phases using appropriate thermodynamic databases. The study was complemented with the determination of the lead isotopic composition of waters with the objective of comparing with previously published isotopic data from the zone.

\section{METHODOLOGY}

\section{Studied area}

The mining region of Taxco de Alarcón is located in northern Guerrero State in southern Mexico at $18^{\circ} 33^{\prime} 16^{\prime \prime} \mathrm{N}$ and $99^{\circ} 36^{\prime} 21^{\prime \prime} \mathrm{W}$ (Figure 1). Lithology in the area includes metamorphosed, intermediate to acidic volcanics of the Taxco Volcanosedimentary Sequence of early Cretaceous age; limestone and dolostone of the Morelos
Formation of Albian-Cenomanian age; sandstone, shale and minor marl of the Mexcala Formation of Turonian-Maastrichtian age; red beds of the Balsas Group of Eocene age and acidic volcanics of the Tilzapotla Formation of Eocene-Oligocene age (Campa and Ramírez, 1979; Campa et al., 2012). The economic geology of the zone was summarized by Farfán-Panamá et al. (2015) and consists of base $(\mathrm{Cu}-$ $\mathrm{Pb}-\mathrm{Zn}$ ) and precious (Ag-Au) intermediate to low sulfidation veins, stockworks and replacement mantos emplaced at $\sim 34 \mathrm{Ma}$. Structures are mainly emplaced in limestone, dolostone and marls of the Morelos and Mexcala formations though mineralized structures have been recognized in the whole stratigraphic column.

In the last century, ores in Taxco have been processed using the selective flotation method and the resulting tailings have been dumped in eight major impoundments containing around 55 million tons (e.g. Talavera et al., 2005). The mineralogical and chemical composition of tailings has been studied by Armienta et al. (2003); Talavera et al. (2005) and Romero et al. (2007), who based on the mineralogy and acid-base mass balance, agree that the tailings have great potential for producing acid mine drainage and to release significant amounts of toxic elements to the environment. Although AMD is undoubtedly generated as pore water in oxidized tailings, it has not been reported as a major environmental problem in the Taxco mining area, very likely because of the great buffer capacity of bedrock (Romero et al., 2011). However, in the Guerrero Mine, highly acidic waters are routinely pumped to the surface in order to control the phreatic level, which are directly discharged to the Xochula stream, an affluent of the Taxco River (Figures 1 and 2). This stream is $\sim 2.0 \mathrm{~km}$ long and begins in the suburbs of Taxco city, in the vicinity of the El Solar Mine and flows on calcareous sandstone and shale of the Mexcala Formation. The Xochula stream receives leachates from the El Solar tailings impoundment only in the rainy season, which flow for around $500 \mathrm{~m}$ before reaching the discharge point at the Guerrero Mine. After this point, the stream dissects the highly oxidized tailings from the Guerrero II impoundment and flows for $1.5 \mathrm{~km}$ to its mouth with the Taxco River (Figure 1).

\section{Sampling and chemical analysis}

Thirteen points spanning from the Guerrero Mine to the mouth of Xochula stream with Taxco River were selected for sampling (Figure 2). Water samples were taken seasonally in November 2014 (fall), February (winter), May (spring) and August (summer) 2015. Sample XO-01 was taken at the Guerrero Mine and is thought to represent the departing acid water discharged to the stream. Sample XO-02 was taken $100 \mathrm{~m}$ upstream from point XO-01 and corresponds to water coming from the El Solar tailings Dam after neutralization by bedrock. Samples XO-05 and XO-09 were taken from tributaries of the Xochula stream. Samples XO-03 and XO-06 were taken from the Xochula stream dissecting coarse, unoxidized tailings of the Guerrero II deposit and the remaining (XO-08, XO-09, XO-10, XO-11 XO-12, $\mathrm{XO}-14, \mathrm{XO}-15, \mathrm{XO}-16$ and $\mathrm{XO}-17$ ) samples correspond to water from the Xochula stream dissecting highly oxidized tailings of the same deposit. Because AMD is periodically discharged from the mine, the flow rate varies enormously from one moment to another depending on the pumping time (which is not always the same) and the moment in which the flow is measured. In consequence, any measurement of the flow could not be quantitatively correlated with any other physicochemical parameter and so, in this study flow was not measured in any sampling point or season.

At each sampling point, three aliquots of water were taken in acid-washed HPDE bottles. Two of $1 \mathrm{~L}$ each for anion and lead isotope determinations and one of $0.5 \mathrm{~L}$ acidified with ultrapure $\mathrm{HNO}_{3}$ for the determination of total cations. Around $100 \mathrm{~mL}$ of water were further filtered using disposable syringes with $0.45 \mu \mathrm{m}$ filters and acidified to 


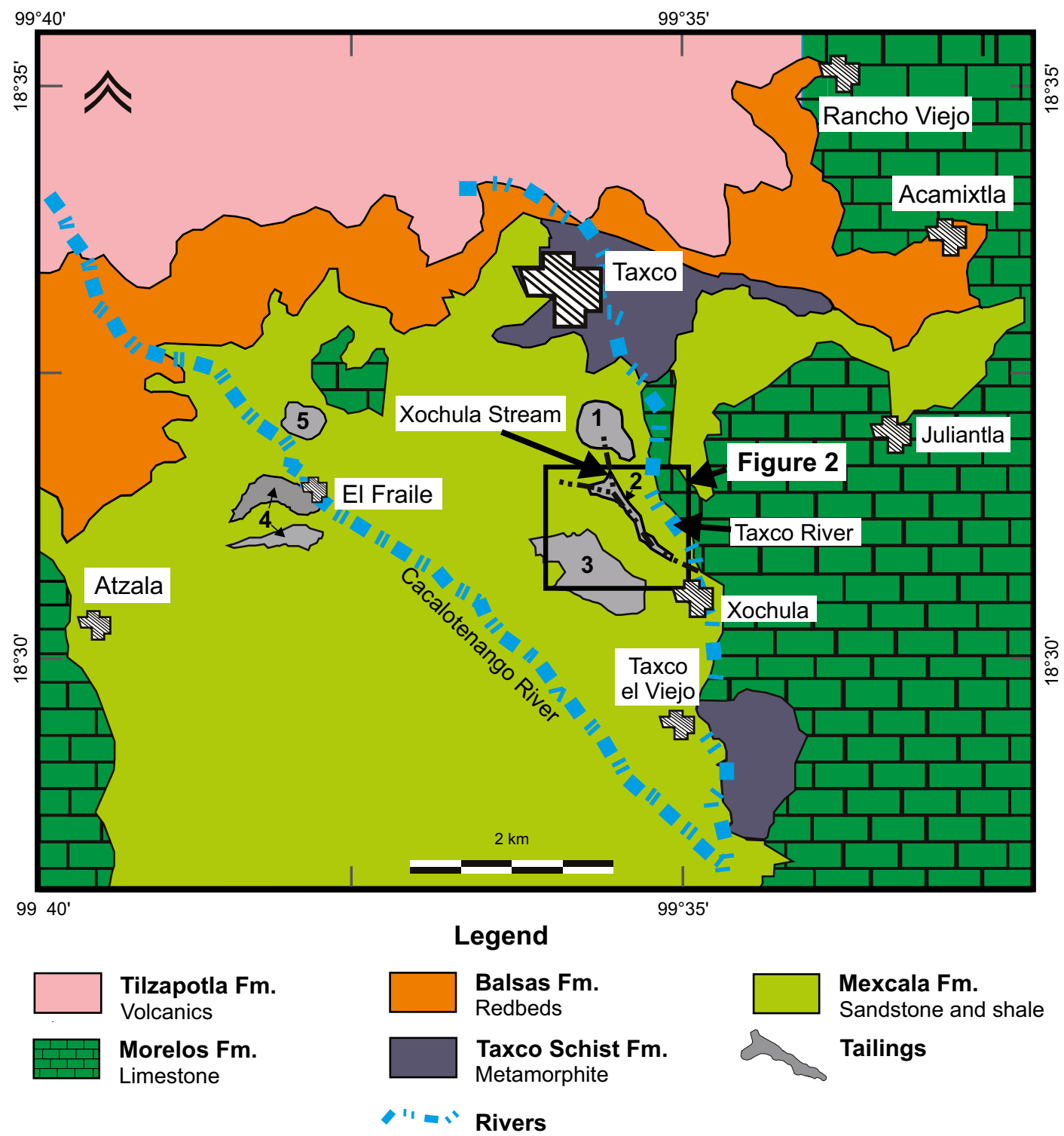

Figure 1. Geological map of the Taxco, Guerrero region after Campa and Ramírez (1979) showing the location of major tailings impoundments. Inset shows the location of studied samples. Leveled tailings deposits are: 1) El Solar; 2) Guerrero I; 3) Guerrero II; 4) El Fraile; and, 5) La Concha.

pH 2 with ultrapure $\mathrm{HNO}_{3}$ for dissolved metals. Temperature, $\mathrm{pH}$, electrical conductance (EC) and redox potential (Eh) were measured in situ using portable potentiometers according to the procedure described by Talavera et al. (2006). Samples were analyzed in the Laboratory of Geochemistry of the Autonomous University of Guerrero. Alkalinity was determined by titration with $0.02 \mathrm{M} \mathrm{HCl}$ and phenolphthaleinbromocresol green-methyl red as colorimetric indicators whereas chlorides were determined with $0.01 \mathrm{M} \mathrm{AgNO}_{3}$ and potassium chromate as a colorimetric indicator. Sulfate, fluoride and nitrate were measured by the colorimetric method using a Hach DR890 colorimeter and appropriate reagents. Total and soluble cations excepting sodium, were determined by inductively coupled plasma-atomic emission spectrometry (ICP-AES) using a Perkin Elmer Optima 3200 DV. Sodium was measured by flame atomic emission spectrometry using a Perkin Elmer Analyst 100 instrument. Four High-Purity Certified Standards of Wastewater (CWW-TM-D; CWWTM-H; CWW-TM-A and CWW-TM-E) were used for calibration and for checking ac- curacy and precision. The quantification limits of analyzed elements and the data obtained from analytical techniques that were used are reported in Table S1. Hydrogechemical results are compared with the Mexican Guideline NOM-001-SEMARNAT-1996 when appropriated. Geochemical speciation and the Saturation Index (SI) of total contents were determined using the PHREEQC (Parkhurst 1995) equilibrium models with the WATEQ4F database (Ball and Nordstrom 1991).

\section{Lead isotopic determinations}

Eleven samples (XO-01, XO-03, XO-06, XO-08, XO-10, XO-11, $\mathrm{XO}-12$, XO-14, XO-15, XO-16 and XO-17) of AMD collected during the fall sampling season as well as three samples (XO-02, $\mathrm{XO}-05$ and $\mathrm{XO}-09)$ from tributaries were analyzed for $\mathrm{Pb}$ isotopic composition. Purification of $\mathrm{Pb}$ was carried out by liquid chromatography using columns with Sr Spect Resin (Eichrom Technologies LLC) according to the procedure described by Thibodeau et al. (2013). Lead isotope ratios were measured in $\sim 50 \mathrm{ppb}$, Tl-spiked aliquots and isotopic fractionation 


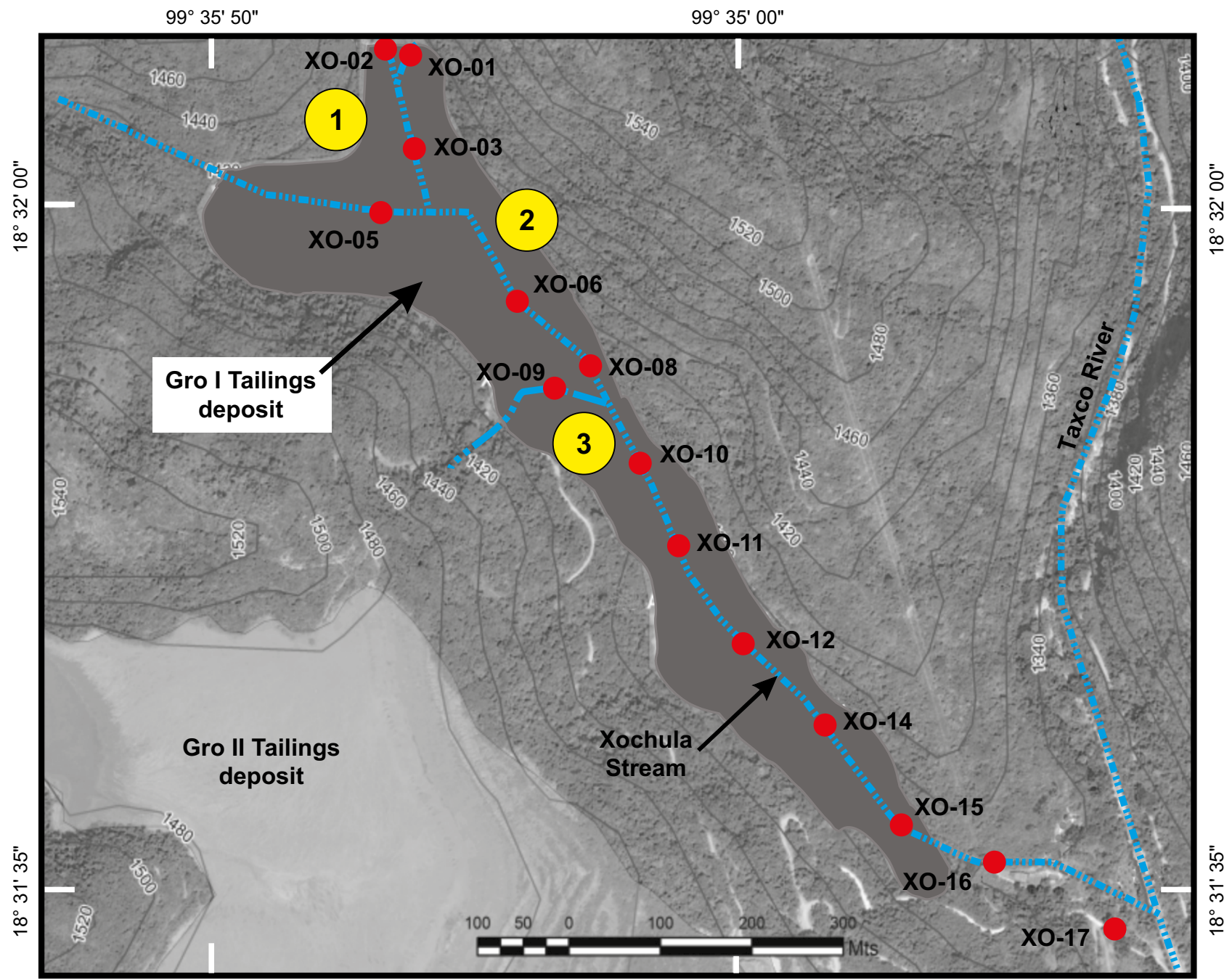

$99^{\circ} 35^{\prime} 50^{\prime \prime}$

$99^{\circ} 35^{\prime} 00^{\prime \prime}$

Figure 2. Satellite image of the Xochula Stream from the mining region of the Taxco, Guerrero showing the location of studied samples. Numbered yellow circles indicate the sites used to evaluate the role of the AMD-freshwater mixing in the neutralization process in the Xochula stream and red circles indicate AMD and tributary sampling sites.

was checked by analyzing the NBS-981 standard $\left({ }^{206} \mathrm{~Pb} /{ }^{204} \mathrm{~Pb}=16.9405\right.$; ${ }^{207} \mathrm{~Pb} /{ }^{204} \mathrm{~Pb}=15.4963$ and ${ }^{208} \mathrm{~Pb} /{ }^{204} \mathrm{~Pb}=36.7219$; Galer and Abouchami, 1998).

\section{RESULTS}

Based on the variations recorded in both physicochemical parameters and elemental concentrations, the studied samples can conveniently be grouped into two categories: Sample XO-02 and the tributaries XO-05 and XO-09 are ascribed to Group I whereas the remaining samples (Table S1), belonging to water from the Xochula stream, are ascribed to Group II. Hereafter, we follow this grouping for describing samples.

Physicochemical parameters, major ions and water classification

The temperature of water oscillated from 16.5 to $26.4{ }^{\circ} \mathrm{C}$, which is within the range of the ambient temperature recorded in the zone. The $\mathrm{pH}$ was circum-neutral (6.10 to 7.95$)$ in samples of Group I and highly variable $(2.20$ to 7.04$)$ but mostly acidic $(<6.0)$ in samples of
Group II. The pH correlated inversely with the EC, which varied from 0.73 to $3.12 \mathrm{mS} / \mathrm{cm}$ in samples of Group I and from 1.99 to $10.3 \mathrm{mS} / \mathrm{cm}$ in samples of Group II. Redox conditions were also variable with values of Eh of 193.5-253.1 mV in samples of Group I and of 72.7-769 mV in samples of Group II. The large variations recorded in these three parameters highlight the changing physicochemical conditions prevailing in the Xochula stream during the year.

Bicarbonate was not recorded in samples with $\mathrm{pH}<6.0$ and was quite variable $\left(65-573.4 \mathrm{mg} \cdot \mathrm{L}^{-1}\right)$ in samples with higher $\mathrm{pH}$. There is no obvious correlation between $\mathrm{pH}$ and bicarbonate contents $\left(\mathrm{R}^{2}=0.251\right)$. Concentrations of $\mathrm{SO}_{4}{ }^{2-}$ were variable but systematically high (800-7600 $\left.\mathrm{mg} \cdot \mathrm{L}^{-1}\right)$ and no significant differences existed among samples regardless of the group. The correlation of $\mathrm{SO}_{4}{ }^{2-}$ with the EC was moderate $\left(\mathrm{R}^{2}=0.538\right)$ suggesting that $\mathrm{SO}_{4}{ }^{2-}$ is a reactive specie influencing conductance. Chloride could not be determined in samples with $\mathrm{pH}<6.0$ because as, has long been known, transformation of chromate ions to chromic acid prevents the precipitation of silver chromate at the equivalent point. In the remaining samples, $\mathrm{Cl}^{-}$contents ranged from 7.70 to $74.88 \mathrm{mg} \cdot \mathrm{L}^{-1}$.

Total contents of major cations were moderate but variable in all 
samples from all the sampling seasons and fall within the range recorded in surface water in the zone (Cole, 2004; Talavera et al., 2016). The concentration of Ca ranged from 125 to $688 \mathrm{mg} \cdot \mathrm{L}^{-1}$ whereas the concentration of $\mathrm{Mg}$ was variable ranging from 9.36 to $471 \mathrm{mg} \cdot \mathrm{L}^{-1}$. The contents of $\mathrm{Na}$ were lower falling in the range of 5.48 to $71.0 \mathrm{mg} \cdot \mathrm{L}^{-1}$ (total) and the K varied from 1.32 to $21.9 \mathrm{mg} \cdot \mathrm{L}^{-1}$.

According to the Stiff classification scheme, water of Group I belongs to the $\mathrm{SO}_{4}$-Ca type whereas water of Group II belongs to the $\mathrm{SO}_{4}-\mathrm{Mg}$ type (Figure 3). These types of water are similar to those recorded in the tailings leachates from El Fraile, $5 \mathrm{~km}$ west of the studied area (Talavera et al., 2016) and have classically been reported in many mining areas worldwide (e.g. Campaner et al., 2014; Atirah-Affandi et al., 2018).

\section{Total and soluble concentrations of trace elements}

The total and soluble concentrations of metal(oid)s recorded in the samples from the four sampling seasons are presented in Table S1. Waters of Group I had total concentrations of $\mathrm{Al}<0.25 \mathrm{mg} \cdot \mathrm{L}^{-1}$ with most samples having concentrations below the quantification limit $(<\mathrm{QL})$, whereas their soluble concentrations were systematically $<$ QL. Contrastingly, waters of Group II had high and variable concentrations of total and soluble $\mathrm{Al}$ ranging from 4.46 to $177 \mathrm{mg} \cdot \mathrm{L}$ ${ }^{1}$ and from 0.053 to $179 \mathrm{mg} \cdot \mathrm{L}^{-1}$, respectively. The proportion of soluble/total $\mathrm{Al}$ varied greatly. In samples with $\mathrm{pH}<4.50$, this ratio was $>0.70$ indicating that most $\mathrm{Al}$ was dissolved whereas in samples with higher $\mathrm{pH}$, the ratio fell to $<0.35$ showing that $\mathrm{Al}$ was mostly transferred to the particulate phase.

The concentration of total $\mathrm{Cu}$ was $<\mathrm{QL}$ in samples of Group I with the exception of two samples from the summer sampling season which had 0.038 and $0.054 \mathrm{mg} \cdot \mathrm{L}^{-1}$. Soluble Cu was systematically $<$ QL in samples of this group. In samples of Group II, the concentrations of total and soluble $\mathrm{Cu}$ oscillated from 0.169 to 22.5 and from 0.027 to 14.8 $\mathrm{mg} \cdot \mathrm{L}^{-1}$, respectively. This element is regulated by the Mexican Guideline for discharging waters to rivers (NOM-001-SEMARNAT-1996) establishing a maximum (monthly average) of $4.0 \mathrm{mg} \cdot \mathrm{L}^{-1} \mathrm{of} \mathrm{Cu}$. Most of the samples having $\mathrm{pH}<3.0(\sim 30 \%)$ were above this guideline in both, total and soluble contents. As observed in the case of $\mathrm{Al}$, the soluble/total ratio of $\mathrm{Cu}$ was also contrasting. In most samples with $\mathrm{pH}<4.50$, the ratio was $>0.55$ and at higher $\mathrm{pH}$, the ratio varied from 0.003 to 0.50 suggesting that $\mathrm{Cu}$ was essentially dissolved in acidic waters and that, at higher $\mathrm{pH}$ conditions, it was sequestered by the particulate phase.

The total and soluble concentrations of Fe in samples of Group I ranged from 0.158 to $6.11 \mathrm{mg} \cdot \mathrm{L}^{-1}$ and from 0.044 to $3.23 \mathrm{mg} \cdot \mathrm{L}^{-1}$, respectively whereas in samples of Group II, they varied widely from 6.97 to $619 \mathrm{mg} \cdot \mathrm{L}^{-1}$ and from 0.030 to $564 \mathrm{mg} \cdot \mathrm{L}^{-1}$, respectively. The soluble/total ratio of this element varied from 0.43 to 1.0 with mostly $>0.75$ in samples with $\mathrm{pH}<5.50$ and fell drastically to $<0.30$ in samples with higher $\mathrm{pH}$ demonstrating that Fe was controlled by the precipitation of oxihydroxides occurring at $\mathrm{pH} \sim 6.00$ (Lee et al., 2002; Jambor, 2003;).

The concentrations of total (<QL to $\left.1.350 \mathrm{mg} \cdot \mathrm{L}^{-1}\right)$ and soluble $(<$ QL to $\left.1.010 \mathrm{mg} \cdot \mathrm{L}^{-1}\right) \mathrm{Mn}$ in waters from Group I were contrastingly lower relative to those recorded in waters from Group II, which ranged from 5.82 to $151 \mathrm{mg} \cdot \mathrm{L}^{-1}$ and from 0.446 to $148 \mathrm{mg} \cdot \mathrm{L}^{-1}$, respectively. With the exception of a few samples from tributaries of Group I and one of the Xochula stream, most Mn occurred in the dissolved form with soluble/ total ratios $>0.60$ (mostly are $>0.75$ ).

As a whole, $\mathrm{Zn}$ had the highest total concentrations recorded among the trace elements. It ranged from 0.144 to $37.4 \mathrm{mg} \cdot \mathrm{L}^{-1}$ in samples of Group I and from 55 to $863 \mathrm{mg} \cdot \mathrm{L}^{-1}$ in samples of Group II. The soluble concentrations were also high ranging from 0.299 to $22.3 \mathrm{mg} \cdot \mathrm{L}^{-1}$ in samples of Group I and from 19.9 to $681 \mathrm{mg} \cdot \mathrm{L}^{-1}$ in samples of Group II. Zinc is regulated by the Mexican Regulatory Norm (NOM-001-SEMARNAT-1996) for discharging water to rivers establishing a maximum (monthly average) of $10.0 \mathrm{mg} \cdot \mathrm{L}^{-1}$. Samples from all the sampling seasons were well above this guideline in both, total and soluble contents with many samples having up to 80 times the regulatory level in total contents and up to 50 times the soluble contents. The soluble/total ratio was moderate to high (0.32 to 1.0$)$ excepting for some samples of Group I, which had ratios $<0.30$.

Arsenic, $\mathrm{Cd}$ and $\mathrm{Pb}$ are toxic elements of major environmental and toxicological concern in the zone (Moreno et al., 2010; Vázquez-Bahena et al., 2017; Soto-Ríos et al., 2017). The total and soluble concentrations of As were $<0.172 \mathrm{mg} \cdot \mathrm{L}^{-1}$ and $<0.072 \mathrm{mg} \cdot \mathrm{L}^{-1}$, in samples of Group I and $<$ QL to $0.670 \mathrm{mg} \cdot \mathrm{L}^{-1}$ and < QL to $0.085 \mathrm{mg} \cdot \mathrm{L}^{-1}$, in samples of Group II. Arsenic is also regulated by the Mexican Guideline in the NOM001-SEMARNAT-1996 establishing a maximum (monthly average) of $0.200 \mathrm{mg} \cdot \mathrm{L}^{-1}$ of As in discharging waters. Seven samples had total concentrations of As just above this guideline and all samples met the guideline in soluble contents. Most samples had soluble As < QL and thus, the soluble/total ratio in those samples was nearly zero; in the other samples, this ratio, though variable overall (0.007-1.0), was between 0.16 and 0.50 in most samples strongly suggesting that As was mostly bound to the particulate material.

The total and soluble concentrations of Cd ranged from $<\mathrm{QL}$ to $0.298 \mathrm{mg} \cdot \mathrm{L}^{-1}$ and from $<\mathrm{QL}$ to $0.211 \mathrm{mg} \cdot \mathrm{L}^{-1}$, respectively in samples of Group I. In samples of Group II, they varied from 0.291 to $6.39 \mathrm{mg} \cdot \mathrm{L}^{-1}$ and from 0.164 to $5.53 \mathrm{mg} \cdot \mathrm{L}^{-1}$, respectively. Cadmium is also regulated in the NOM-001-SEMARNAT-1996 establishing a maximum (monthly average) of $0.200 \mathrm{mg} \cdot \mathrm{L}^{-1}$ of Cd discharged to rivers. With the exception of samples having concentrations below the detection limit and the sample XO- 15 of the spring sampling season, which had soluble concentrations $<0.200 \mathrm{mg} \cdot \mathrm{L}^{-1}$, the remaining samples were well above regulatory guidelines in both total and soluble contents, exceeding the regulation by up to 32 times and 27.7 times, respectively. The soluble/ total ratios were $>0.55$ in all samples and more than $80 \%$ had ratios $>0.75$ indicating that $\mathrm{Cd}$ remained soluble, similar to the behavior recorded in $\mathrm{Zn}$.

The total and soluble concentrations of $\mathrm{Pb}$ were below $\mathrm{DL}$ in samples of Group I and ranged from 0.033 to $1.44 \mathrm{mg} \cdot \mathrm{L}^{-1}$ and from 0.018 to $1.04 \mathrm{mg} \cdot \mathrm{L}^{-1}$, respectively in samples of Group II. Lead is regulated in the NOM-001-SEMARNAT-1996 establishing a maximum (monthly average) of $0.5 \mathrm{mg} \cdot \mathrm{L}^{-1}$ of $\mathrm{Pb}$. Only some acidic $(\mathrm{pH}<3.1)$ samples from Group II had total and soluble $\mathrm{Pb}$ above the Mexican guideline, exceeding it by up to 2.8 and 2.1 times, respectively. The soluble/total ratio of $\mathrm{Pb}$ was more erratic than in other elements although there was a clear tendency in acidic samples with $\mathrm{pH}<4.50$ to have ratios $>0.70$ indicating predominance of soluble forms, which dropped to values near zero in the less acidic to neutral waters indicating (co)precipitation of $\mathrm{Pb}$ during neutralization.

\section{Lead isotopes}

$\mathrm{The} \mathrm{Pb}$ isotopic composition of waters from the fall sampling season is presented in Table 1 and shown in Figure 4. The isotopic composition of AMD is slightly variable with ${ }^{206} \mathrm{~Pb} /{ }^{204} \mathrm{~Pb}$ ratios ranging from 18.9296 to $19.0320 ;{ }^{207} \mathrm{~Pb} /{ }^{204} \mathrm{~Pb}$ ratios from 15.6455 to 15.6786 ; and, ${ }^{208} \mathrm{~Pb} /{ }^{204} \mathrm{~Pb}$ from 38.5959 to 38.7990 , whereas in the tributaries the isotopic composition is more homogeneous with ${ }^{206} \mathrm{~Pb} /{ }^{204} \mathrm{~Pb}$ ratios ranging from 18.7242 to $18.9467 ;{ }^{207} \mathrm{~Pb} /{ }^{204} \mathrm{~Pb}$ ratios from 15.6435 to 15.6721; and, ${ }^{208} \mathrm{~Pb} /{ }^{204} \mathrm{~Pb}$ from 38.5223 to 38.6716 . The range of the $\mathrm{Pb}$ isotopic composition recorded in the Xochula stream falls within the range recorded in mineralization, circum-neutral leachates from $\mathrm{El}$ Fraile tailings and in rocks from all the lithological formations recognized in the zone (Talavera et al., 2016, Vázquez-Bahena et al., 2017). 

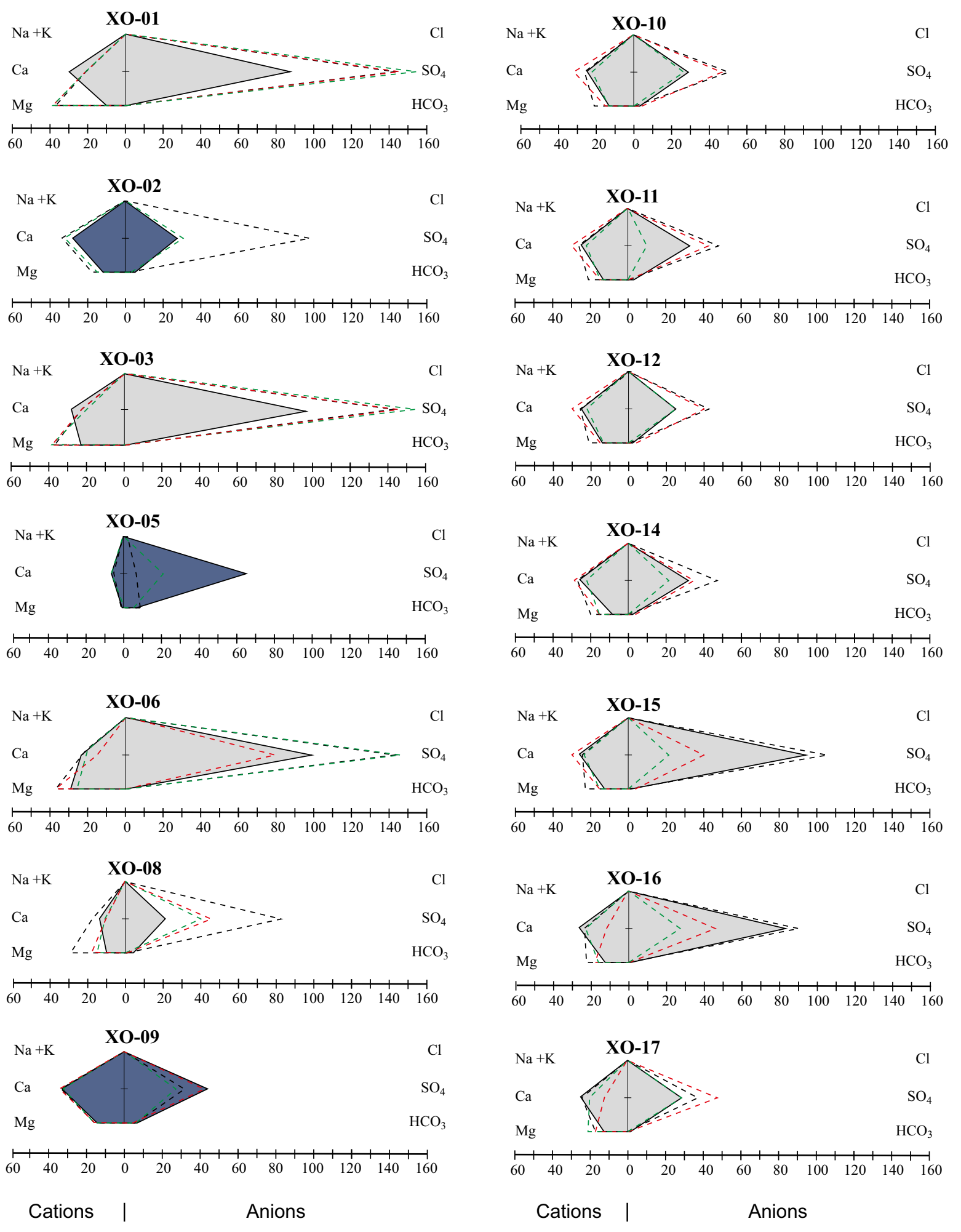

Cations I Anions

\section{Concentration $(\mathbf{m e q} / \mathrm{L})$}

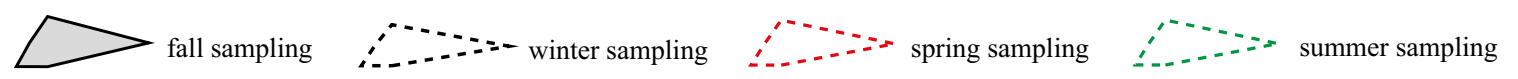

Figure 3. Stiff diagrams of studied waters along the Xochula stream in all the seasons. Deep blue fields indicate samples from tributaries belonging to Group I and gray fields indicate samples from the Xochula stream belonging to Group II. 


\section{DISCUSSION}

\section{Spatial and seasonal behavior of trace elements in the Xochula stream}

Figure 5 shows the variations recorded in the $\mathrm{pH}, \mathrm{EC}$ and the total and soluble concentrations of metals ( $\mathrm{Al}, \mathrm{Cu}, \mathrm{Fe}, \mathrm{Mn}, \mathrm{Zn}$, $\mathrm{Cd}, \mathrm{Pb}$ ) and $\mathrm{As}$ in the AMD along the stream in the four sampling seasons. Physicochemical parameters and both, total and soluble trace element concentrations, showed significant spatial, though less evident temporal, variations. Variations of the contents of $\mathrm{SO}_{4}{ }^{2-}$ and major cations $(\mathrm{Ca}, \mathrm{Mg}, \mathrm{Na}, \mathrm{K})$ show the same pattern but they are not presented in this article. The behavior of the EC and trace elements reveals a major chemical breaking point in the AMD between the samples XO-06 and XO-08 in all the sampling seasons. Between these two points, the EC and the total and soluble metal contents decreased significantly and the $\mathrm{pH}$ increased only during the fall season. In the other seasons, the greatest change in $\mathrm{pH}$ occurred between samples XO-08 and XO-10. As substantiated later, at these points and all along the Xochula stream, bedrock is calcareous shale and sandstone of the Mexcala Formation (Figure 1) with no observable mineralogical or chemical variations. The abrupt change in the chemistry of water cannot be due to changes in the bedrock. Instead, between these two points, the AMD is conducted through a culvert made of concrete of approximately $15 \mathrm{~m}$ long, which crosses below a pedestrian bridge. Depending on the flow rate, the time of interaction between AMD and the culvert may vary between 30 to $60 \mathrm{~s}$. Sample XO-08 was taken at the outlet of the culvert and is the sample experiencing the major chemical change along the Xochula stream. This suggests that concrete plays an important role in the neutralization of AMD of the Xochula stream.

Table 1. Lead isotopic composition of AMD and tributaries from the fall sampling season of the Xochula stream in Taxco Guerrero, Mexico. Gray files highlight tributaries of Group I. Source of data: (1)This study; (2)Vázquez-Bahena et al. (2017); (3) Cummings (1979); (4)Talavera et al. (2016).

\begin{tabular}{|c|c|c|c|c|c|}
\hline Sample & ${ }^{206} \mathrm{~Pb} /{ }^{204} \mathrm{~Pb}$ & ${ }^{207} \mathrm{~Pb} /{ }^{204} \mathrm{~Pb}$ & ${ }^{208} \mathrm{~Pb} /{ }^{204} \mathrm{~Pb}$ & ${ }^{207} \mathrm{~Pb} /{ }^{206} \mathrm{~Pb}$ & ${ }^{208} \mathrm{~Pb} /{ }^{206} \mathrm{~Pb}$ \\
\hline \multicolumn{6}{|c|}{ Xochula stream and tributaries ${ }^{(1)}$} \\
\hline XO-01 & 18.7334 & 15.6564 & 38.6548 & 0.8358 & 2.0634 \\
\hline $\mathrm{XO}-02$ & 18.7800 & 15.6435 & 38.6279 & 0.8330 & 2.0569 \\
\hline $\mathrm{XO}-03$ & 18.7435 & 15.6528 & 38.7135 & 0.8351 & 2.0654 \\
\hline $\mathrm{XO}-05$ & 18.9467 & 15.6721 & 38.6716 & 0.8272 & 2.0411 \\
\hline $\mathrm{XO}-06$ & 18.7406 & 15.6517 & 38.7114 & 0.8352 & 2.0656 \\
\hline $\mathrm{XO}-08$ & 18.7436 & 15.6515 & 38.7057 & 0.8350 & 2.0650 \\
\hline XO-09 & 18.7242 & 15.6563 & 38.5223 & 0.8362 & 2.0573 \\
\hline $\mathrm{XO}-10$ & 18.7296 & 15.6490 & 38.5959 & 0.8355 & 2.0607 \\
\hline $\mathrm{XO}-11$ & 18.7063 & 15.6742 & 38.7990 & 0.8379 & 2.0741 \\
\hline $\mathrm{XO}-12$ & 18.7717 & 15.6591 & 38.6094 & 0.8342 & 2.0568 \\
\hline $\mathrm{XO}-14$ & 18.7438 & 15.6496 & 38.7058 & 0.8349 & 2.0650 \\
\hline $\mathrm{XO}-15$ & 18.7786 & 15.6455 & 38.6362 & 0.8332 & 2.0575 \\
\hline $\mathrm{XO}-16$ & 19.0320 & 15.6786 & 38.7492 & 0.8238 & 2.0360 \\
\hline $\mathrm{XO}-17$ & 18.8910 & 15.6632 & 38.6973 & 0.8291 & 2.0484 \\
\hline \multicolumn{6}{|l|}{ Taxco Mineralization ${ }^{(2)}$} \\
\hline MP-4 (Pyrite) & 18.7242 & 15.6523 & 38.7139 & 0.8359 & 2.0676 \\
\hline MM-7 (Sphalerite) & 18.7621 & 15.6532 & 38.7203 & 0.8343 & 2.0638 \\
\hline MR-8 (Rhodochrosite) & 18.9812 & 15.8405 & 39.1813 & 0.8345 & 2.0642 \\
\hline MP-11 (Pyrite) & 18.7858 & 15.6513 & 38.7093 & 0.8331 & 2.0606 \\
\hline MT-3 /Tennantite) & 18.7534 & 15.6525 & 38.7195 & 0.8346 & 2.0647 \\
\hline MG-9 (Galena) & 18.7582 & 15.6524 & 38.7220 & 0.8344 & 2.0643 \\
\hline \multicolumn{6}{|l|}{ Taxco Mineralization ${ }^{(3)}$} \\
\hline Tax-5 & 18.748 & 15.658 & 38.747 & 0.835 & 2.067 \\
\hline $786(\mathrm{~J})$ & 18.739 & 15.643 & 38.691 & 0.835 & 2.065 \\
\hline 787 (SA-1) & 18.731 & 15.625 & 38.642 & 0.834 & 2.063 \\
\hline 792 (SA-EC) & 18.723 & 15.623 & 38.626 & 0.834 & 2.063 \\
\hline $788(\mathrm{H})$ & 18.73 & 15.638 & 38.695 & 0.835 & 2.066 \\
\hline \multicolumn{6}{|c|}{ Leachates from El Fraile Tailings( ${ }^{(4)}$} \\
\hline JF-01 & 18.8523 & 15.6656 & 38.7255 & 0.8310 & 2.0542 \\
\hline $\mathrm{JF}-02$ & 18.8553 & 15.6616 & 38.7216 & 0.8306 & 2.0536 \\
\hline JF-03 & 18.8592 & 15.6625 & 38.7200 & 0.8305 & 2.0531 \\
\hline JF-04 & 18.8523 & 15.6685 & 38.7211 & 0.8311 & 2.0539 \\
\hline JF-06A & 18.7528 & 15.6536 & 38.7209 & 0.8347 & 2.0648 \\
\hline JF-6B & 18.7520 & 15.6550 & 38.7190 & 0.8348 & 2.0648 \\
\hline JF-07 & 18.7514 & 15.6517 & 38.7124 & 0.8347 & 2.0645 \\
\hline JF-08 & 18.7536 & 15.6527 & 38.7160 & 0.8347 & 2.0645 \\
\hline \multicolumn{6}{|l|}{ Geological Formations } \\
\hline Taxco Schist Fm ${ }^{(4)}$ & 19.7797 & 15.7042 & 38.9708 & 0.7940 & 1.9702 \\
\hline \multicolumn{6}{|l|}{ Morelos $\mathrm{Fm}^{(2)}$} \\
\hline Mexcala Fm ${ }^{(4)}$ & 18.8105 & 15.6397 & 38.6710 & 0.8314 & 2.0558 \\
\hline Balsas Fm ${ }^{(4)}$ & 18.9640 & 15.6737 & 38.7850 & 0.8261 & 2.0451 \\
\hline Tilzapotla Fm ${ }^{(4)}$ & 18.7256 & 15.5933 & 38.4978 & 0.8327 & 2.0559 \\
\hline
\end{tabular}



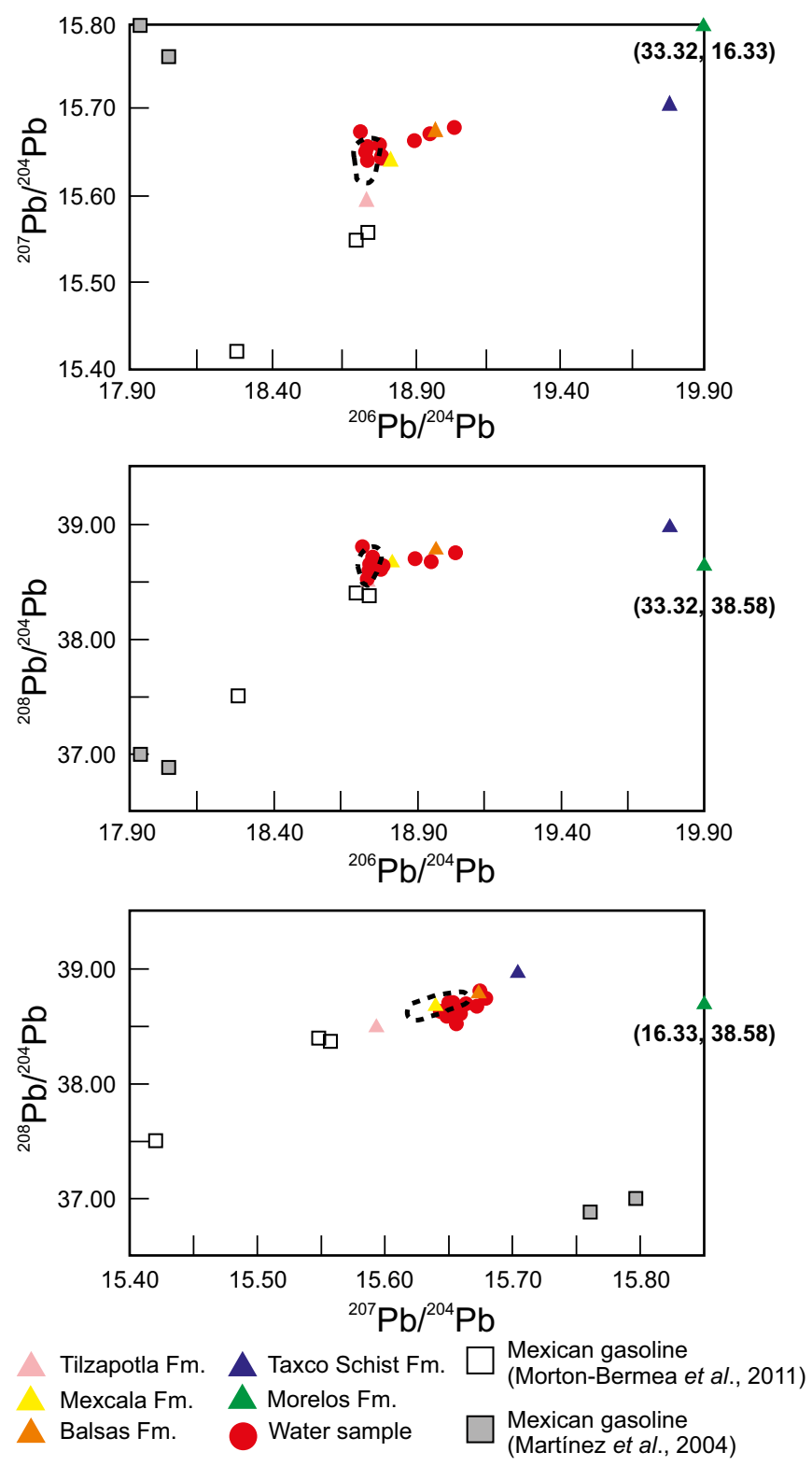

Figure 4. ${ }^{206} \mathrm{~Pb} /{ }^{204} \mathrm{~Pb} v{ }^{207} \mathrm{~Pb} /{ }^{204} \mathrm{~Pb} ;{ }^{206} \mathrm{~Pb} /{ }^{204} \mathrm{~Pb} v{ }^{208} \mathrm{~Pb} /{ }^{204} \mathrm{~Pb}$ and ${ }^{207} \mathrm{~Pb} /{ }^{204} \mathrm{~Pb}$ vs ${ }^{208} \mathrm{~Pb} /{ }^{204} \mathrm{~Pb}$ plots of AMD and tributaries of the Xochula stream in the mining region of Taxco, Guerrero, México. Available $\mathrm{Pb}$ isotopic data of the rocks from the zone after Talavera et al. (2016) and Vázquez-Bahena et al. (2017) as well as of Mexican gasolines after Martínez et al. (2004) and Morton-Bermea et al. (2011) are also plotted for comparison. The dashed field indicates the range of $\mathrm{Pb}$ isotopic composition of the Taxco ore deposits after data of Cummings (1979) and Vázquez-Bahena et al. (2017). Numbers in parentheses close to green triangles (Morelos $\mathrm{Fm}$.) indicate values of the $\mathrm{Pb}$ isotopic ratios in the $\mathrm{X}$-ratios and Y-ratios, respectively.

With the exception of samples from the fall season, samples from the other seasons show additional chemical breaking points between the points XO-14 and XO-15 (winter and spring seasons), and between points $\mathrm{XO}-15$ and $\mathrm{XO}-16$ (summer season). At these points, the $\mathrm{pH}$ drastically dropped and the contents of both total and dissolved metals increased significantly reaching values comparable to those recorded in the AMD at the exit of the mine (sample XO-01). These changes coincide with a significant rise in the level of water in the stream produced by the periodic discharge of flooded mines. Discharge drastically increases the flow rate, which prevents neutralization of AMD even at the point where water is conducted through the culvert.

The AMD of the Xochula stream also records seasonal variations but they are less drastic than the spatial variations. Actually, total and soluble concentrations are similar in the fall, spring and summer seasons whereas the $\mathrm{pH}$ decreases slightly and the total and soluble concentrations increase significantly during the winter (Table S1). These variations may well be attributed to the pre-concentration factor during the winter, which is the driest season in the zone. The concentrations of total and soluble metals and As in the tributaries XO-02, XO-05 and XO-09 (Group II) are very low and their variations are not significant. They are not shown in Figure 5.

Partitioning of metals and As between the total and dissolved phases is varied. Aluminium, $\mathrm{Cu}, \mathrm{Fe}$ and $\mathrm{Pb}$ occur in dissolved species in the most acidic $(\mathrm{pH}<5.5)$ samples but they are predominantly bound to the particulate as precipitated, coprecipitated or adsorbed phases in the less acidic samples from all seasons. In contrast, $\mathrm{Mn}, \mathrm{Zn}$ and Cd principally occur as dissolved phases even in the less acidic samples. Finally, As is strongly bound to particulates regardless the $\mathrm{pH}$ of water samples.

\section{Speciation and Saturation Indexes}

The spatial and temporal chemical variations recorded in the AMD of the Xochula stream turn into a significant number of reactive phases, which seem to control the concentration and partitioning of $\mathrm{As}, \mathrm{Cd}, \mathrm{Cu}, \mathrm{Fe}, \mathrm{Pb}$ and $\mathrm{Zn}$. In this study, we considered a reactive phase as significant if its saturation index is $>-5$ and if at least one sample from any sampling season becomes saturated or nears saturation (Table 2). Figure 6 shows the behavior of reactive phases and the saturation index of AMD from the Xochula stream. Circum-neutral water from tributaries was not included in modelling.

Arsenic occurs in soluble (unsaturated) species in all samples from all the sampling seasons, indicating that concentrations of this element in the AMD are controlled by its adsorption onto Fe and $\mathrm{Mn}$ oxyhydroxides (Wilkie and Hering, 1996). Cadmium also occurs as soluble species in acidic $(\mathrm{pH}<5.5)$ samples from all the sampling seasons. In the remaining samples, $\mathrm{Cd}$ seems to be controlled by otavite $\left(\mathrm{CdCO}_{3}\right)$, which become a saturated or near-saturation phase during neutralization of AMD. Copper has one of the most varied speciations recorded in the $\mathrm{AMD}$ and its concentration and precipitation is controlled by cuprousferrite $\left(\mathrm{CuFeO}_{2}\right)$, which appears as a saturated phase in all the studied samples regardless the $\mathrm{pH}$ and seasonality. Cupricferrite $\left[\mathrm{Cu}\left(\mathrm{FeO}_{2}\right)_{2}\right]$ becomes a saturated phase in samples with $\mathrm{pH}>4.0$ and tenorite $(\mathrm{CuO})$ is near saturation in the less acidic samples. Malachite $\left[\mathrm{Cu}\left(\mathrm{CO}_{3}\right)(\mathrm{OH})_{2}\right]$ is only saturated in sample $\mathrm{XO}-14$ from the spring sampling season but is near-saturation in the samples XO-11, XO-12 and XO-14 to XO- 17 from the fall sampling season and samples $\mathrm{XO}-11$ and $\mathrm{XO}-12$ from the spring season. Although azurite $\left[\mathrm{Cu}\left(\mathrm{CO}_{3}\right)_{2}(\mathrm{OH})_{2}\right]$ appears as an unsaturated phase in all the modelled samples, it is near-saturation in samples XO-11, XO-12 and $\mathrm{XO}-14$ from the fall and spring seasons and thus, this phase together with malachite may play a significant role in the immobilization of $\mathrm{Cu}$ at circum-neutral conditions.

Iron has a similar speciation than $\mathrm{Cu}$. Besides cuprousferrite and cupricferrite described above, goethite $[\alpha-\mathrm{FeO}(\mathrm{OH})]$ and hematite $\left(\mathrm{Fe}_{2} \mathrm{O}_{3}\right)$ are major saturated phases in all the studied samples with the exception of sample $\mathrm{XO}-16$ from both the spring and summer sampling seasons. Maghemite $\left(\mathrm{Fe}_{2} \mathrm{O}_{3}\right)$ and magnetite $\left(\mathrm{Fe}_{3} \mathrm{O}_{4}\right)$ are saturated or near-saturation phases in samples with $\mathrm{pH}>4.0$ from all the sampling seasons. Jarosite $\left[\mathrm{KFe}_{3}\left(\mathrm{SO}_{4}\right)_{2}(\mathrm{OH})_{6}\right]$ is only saturated in sample $\mathrm{XO}-15$ from the summer sampling season but it is a reactive (near-saturation) phase in samples XO-15 and XO-16 from the fall season; XO-11 and 
$\mathrm{XO}-12$ from the spring season and $\mathrm{XO}-06$ and $\mathrm{XO}-14$ from the summer season. Siderite $\left(\mathrm{FeCO}_{3}\right)$ is unsaturated in the most acidic samples but becomes saturated or nears saturation in samples XO-10 to XO-12 and $\mathrm{XO}-14$ to $\mathrm{XO}-17$ from the fall and samples XO-10 to XO-12 and $\mathrm{XO}-14$ from the spring seasons.

Lead has a speciation similar to As, i.e. all modelled phases are unsaturated strongly suggesting that variations in the concentration may be controlled by its adsorption onto $\mathrm{Fe}-\mathrm{Mn}$ oxyhydroxides. However, anglesite $\left(\mathrm{PbSO}_{4}\right)$ is near equilibrium in all samples from all the sampling seasons and cerussite $\left(\mathrm{PbCO}_{3}\right)$ becomes a reactive phase in samples with $\mathrm{pH}>6.0$. Finally, the concentration of $\mathrm{Zn}$ in AMD is controlled by the precipitation of willemite $\left(\mathrm{Zn}_{2} \mathrm{SiO}_{4}\right)$ which becomes saturated in some (XO-11, XO-12 and XO-14) from the spring season and sample $\mathrm{XO}-15$ from the winter season. This phase is near-saturation in many (XO-10 to XO-12, and $\mathrm{XO}-14$ to $\mathrm{XO}-16$ ) samples from the fall sampling season. Smithsonite $\left(\mathrm{ZnCO}_{3}\right)$ appears as a saturated phase in samples XO-11 and XO-14 from the spring season but is near-saturation in some samples from the fall (XO-10,
$\mathrm{XO}-11, \mathrm{XO}-14$ to $\mathrm{XO}-17)$ and spring $(\mathrm{XO}-10)$ seasons. Zincite $(\mathrm{ZnO})$ is a reactive phases in samples $\mathrm{XO}-11, \mathrm{XO}-12, \mathrm{XO}-14$ to $\mathrm{XO}-16$ from the fall, XO-14 from the spring and XO-15 from the summer seasons.

Our results agree well with those reported in many studies dealing on the modelling of the chemical speciation and the role of the absorption and adsorption processes in the immobilization of toxic elements in AMD during its neutralization (e.g. Chapman et al., 1983; Williams and Smith, 2000; Chon and Hwang, 2000; Lachmar et al., 2019).

Neutralization, interaction AMD-bedrock and source of metals

Many studies have demonstrated that interaction of AMD with calcareous (limestone, marl, calcareous sandstone and shale) rocks is an efficient process for neutralizing AMD and inducing massive (co) precipitation of toxic elements (e.g. Webb and Sasowsky, 1994; Watten et al., 2005; Romero et al., 2011; Lakovleva et al., 2015). The efficiency of this process is largely controlled by the grain size of calcareous material and the flow rate of AMD (e.g. Wilmoth, 1974; Makarov et al., 2003; Embile Jr et al., 2016).
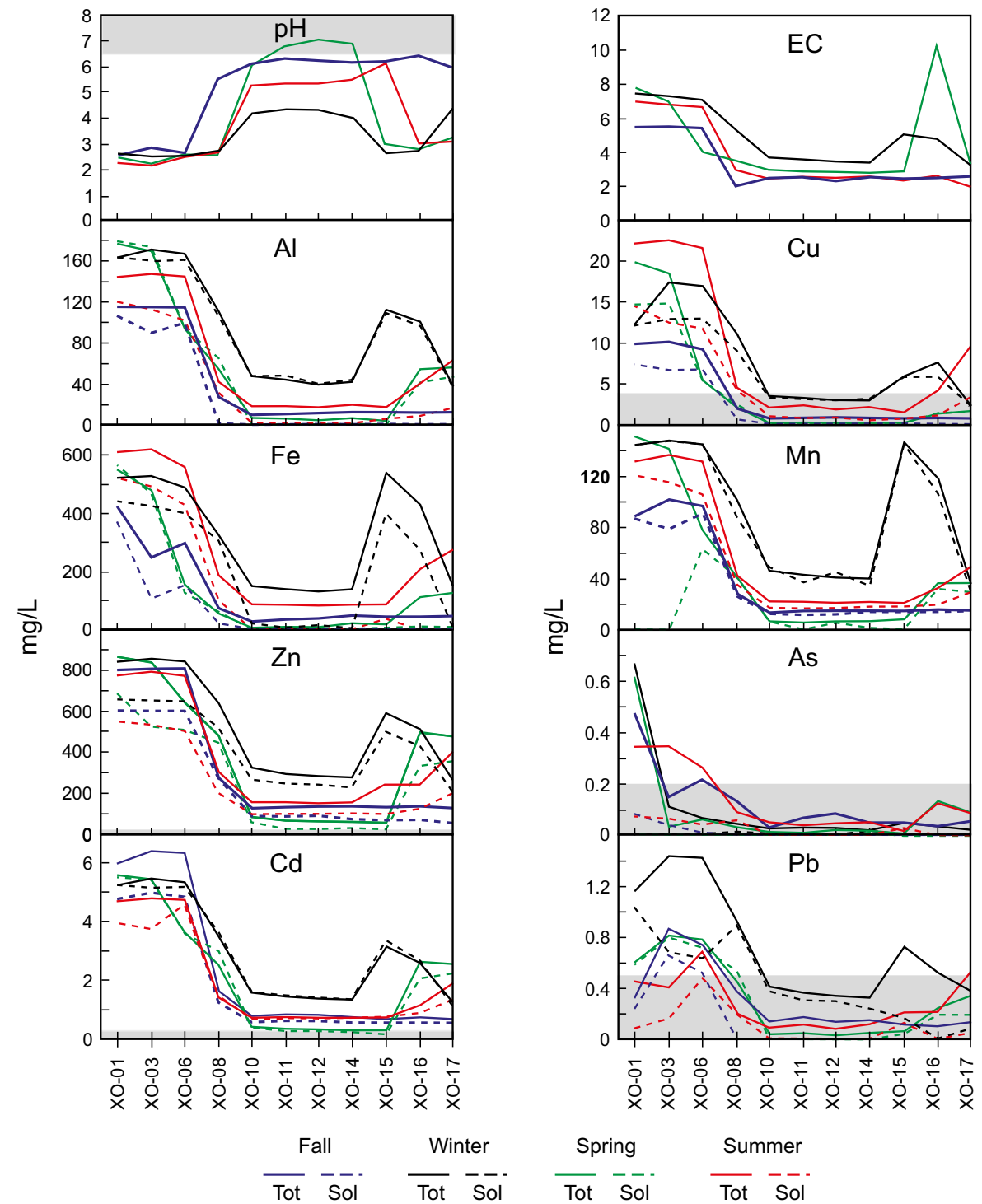

Figure 5. Plots showing the spatial and seasonal behavior of $\mathrm{pH}, \mathrm{EC}(\mathrm{mS} / \mathrm{cm})$ and selected metals and As $(\mathrm{mg} / \mathrm{L})$ in AMD along the Xochula stream. Gray field indicates the maximum limit permitted in the Mexican Guideline NOM-001-SEMARNAT-1996 for water discharge to rivers. 
Table 2. Saturation indices of reactive phases of $\mathrm{Cd}, \mathrm{Cu}, \mathrm{Fe}, \mathrm{Pb}$ and $\mathrm{Zn}$ of AMD from the Xochula Stream of Taxco, Guerrero, Mexico.

\begin{tabular}{|c|c|c|c|c|c|c|c|c|c|c|c|c|c|c|}
\hline & Element & Mineral & Formula & XO-01 & XO-03 & XO-06 & XO-08 & XO-10 & XO-11 & XO-12 & XO-14 & XO-15 & XO-16 & XO-17 \\
\hline \multirow{17}{*}{ 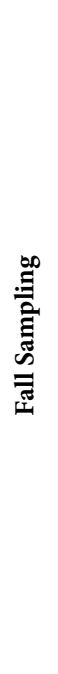 } & $\mathrm{Cd}$ & Otavite & $\mathrm{CdCO}_{3}$ & $<-5.0$ & $<-5.0$ & $<-5.0$ & $<-5.0$ & -0.59 & -0.59 & -0.73 & -1.23 & -1.64 & -1.98 & -1.49 \\
\hline & \multirow[t]{5}{*}{$\mathrm{Cu}$} & Cuprousferrite & $\mathrm{CuFeO}_{2}$ & 1.38 & 2.54 & 1.78 & 12.27 & 12.64 & 14.32 & 14.35 & 14.22 & 13.92 & 14.86 & 13.55 \\
\hline & & Cupricferrite & $\mathrm{CuFe}_{2} \mathrm{O}_{4}$ & $<-5.0$ & $<-5.0$ & $<-5.0$ & 6.20 & 4.94 & 9.68 & 10.61 & 10.57 & 10.32 & 12.60 & 14.44 \\
\hline & & Tenorite & $\mathrm{CuO}$ & $<-5.0$ & $<-5.0$ & $<-5.0$ & -1.71 & -2.07 & -0.87 & -0.77 & -0.86 & -0.98 & -0.49 & -1.17 \\
\hline & & Malachite & $\mathrm{Cu}_{2}\left(\mathrm{CO}_{3}\right)(\mathrm{OH})_{2}$ & $<-5.0$ & $<-5.0$ & $<-5.0$ & $<-5.0$ & -2.84 & -0.82 & -0.66 & -1.13 & -1.52 & -1.35 & -1.63 \\
\hline & & Azurite & $\mathrm{Cu}_{3}\left(\mathrm{CO}_{3}\right)_{2}(\mathrm{OH})_{2}$ & $<-5.0$ & $<-5.0$ & $<-5.0$ & $<-5.0$ & -4.73 & -1.89 & -1.67 & -2.52 & -3.16 & -3.33 & -3.22 \\
\hline & \multirow[t]{6}{*}{$\mathrm{Fe}$} & Goethite & $\mathrm{FeOOH}$ & 0.95 & 0.56 & 0.96 & 4.06 & 3.61 & 5.38 & 5.80 & 5.82 & 5.46 & 6.65 & 7.91 \\
\hline & & Hematite & $\mathrm{Fe}_{2} \mathrm{O}_{3}$ & 3.89 & 3.11 & 3.94 & 10.12 & 9.21 & 12.76 & 13.59 & 13.64 & 13.53 & 15.30 & 17.81 \\
\hline & & Maghemite & $\mathrm{Fe}_{2} \mathrm{O}_{3}$ & $<-5.0$ & $<-5.0$ & $<-5.0$ & -0.06 & -0.94 & 2.64 & 3.43 & 3.49 & 3.32 & 5.12 & 7.70 \\
\hline & & Magnetite & $\mathrm{Fe}_{3} \mathrm{O}_{4}$ & -1.81 & -2.04 & -1.39 & 9.98 & 9.78 & 13.80 & 14.58 & 14.57 & 14.33 & 16.52 & 18.37 \\
\hline & & Jarosite & $(\mathrm{K}, \mathrm{Na}, \mathrm{H}) \mathrm{Fe}_{3}\left(\mathrm{SO}_{4}\right)_{2}(\mathrm{OH})_{6}$ & $<-5.0$ & $<-5.0$ & $<-5.0$ & $<-5.0$ & $<-5.0$ & -4.68 & -3.50 & -3.02 & -2.45 & -0.52 & 3.77 \\
\hline & & Siderite & $\mathrm{FeCO}_{3}$ & $<-5.0$ & $<-5.0$ & $<-5.0$ & $<-5.0$ & 0.10 & 0.21 & 0.10 & -0.24 & -0.51 & -0.92 & -0.49 \\
\hline & \multirow[t]{2}{*}{$\mathrm{Pb}$} & Anglesite & $\mathrm{PbSO}_{4}$ & -0.97 & -0.54 & -0.64 & -1.10 & -1.67 & -1.49 & -1.63 & -1.45 & -1.41 & -1.43 & -1.48 \\
\hline & & Cerussite & $\mathrm{PbCO}_{3}$ & $<-5.0$ & $<-5.0$ & $<-5.0$ & $<-5.0$ & -0.91 & -0.78 & -0.99 & -1.31 & -1.82 & -2.20 & -1.55 \\
\hline & \multirow[t]{3}{*}{$\mathrm{Zn}$} & Zincite & $\mathrm{ZnO}$ & $<-5.0$ & $<-5.0$ & $<-5.0$ & -3.08 & -2.31 & -1.93 & -2.0 & -2.15 & -2.35 & -1.89 & -2.54 \\
\hline & & Willemite & $\mathrm{Zn}_{2} \mathrm{SiO}_{4}$ & $<-5.0$ & $<-5.0$ & $<-5.0$ & -2.36 & -0.89 & -0.12 & -0.29 & -0.57 & -1.03 & -0.08 & -1.38 \\
\hline & & Smithsonite & $\mathrm{ZnCO}_{3}$ & $<-5.0$ & $<-5.0$ & $<-5.0$ & $<-5.0$ & -0.26 & -0.26 & -0.39 & -0.82 & -1.16 & -1.52 & -1.08 \\
\hline \multirow{17}{*}{ 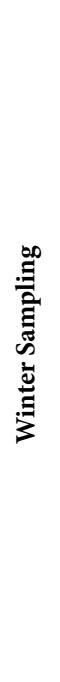 } & $\mathrm{Cd}$ & Otavite & $\mathrm{CdCO}_{3}$ & $<-5.0$ & $<-5.0$ & $<-5.0$ & $<-5.0$ & $<-5.0$ & $<-5.0$ & $<-5.0$ & $<-5.0$ & $<-5.0$ & $<-5.0$ & $<-5.0$ \\
\hline & \multirow[t]{5}{*}{$\mathrm{Cu}$} & Cuprousferrite & $\mathrm{CuFeO}_{2}$ & 1.70 & 1.60 & 1.52 & 2.02 & 7.26 & 7.87 & 7.93 & 6.51 & 1.85 & 1.97 & 7.89 \\
\hline & & Cupricferrite & $\mathrm{CuFe}_{2} \mathrm{O}_{4}$ & $<-5.0$ & $<-5.0$ & $<-5.0$ & $<-5.0$ & 1.64 & 2.10 & 1.76 & -1.09 & $<-5.0$ & -4.39 & 1.88 \\
\hline & & Tenorite & $\mathrm{CuO}$ & $<-5.0$ & $<-5.0$ & $<-5.0$ & $<-5.0$ & -4.26 & -3.96 & -3.92 & -4.64 & $<-5.0$ & $<-5.0$ & -4.04 \\
\hline & & Malachite & $\mathrm{Cu}_{2}\left(\mathrm{CO}_{3}\right)(\mathrm{OH})_{2}$ & $<-5.0$ & $<-5.0$ & $<-5.0$ & $<-5.0$ & $<-5.0$ & $<-5.0$ & $<-5.0$ & $<-5.0$ & $<-5.0$ & $<-5.0$ & $<-5.0$ \\
\hline & & Azurite & $\mathrm{Cu}_{3}\left(\mathrm{CO}_{3}\right)_{2}(\mathrm{OH})_{2}$ & $<-5.0$ & $<-5.0$ & $<-5.0$ & $<-5.0$ & $<-5.0$ & $<-5.0$ & $<-5.0$ & $<-5.0$ & $<-5.0$ & $<-5.0$ & $<-5.0$ \\
\hline & \multirow[t]{6}{*}{$\mathrm{Fe}$} & Goethite & $\mathrm{FeOOH}$ & 0.53 & 0.28 & 0.56 & 0.74 & 3.04 & 3.12 & 2.94 & 1.87 & 0.57 & 1.39 & 3.04 \\
\hline & & Hematite & $\mathrm{Fe}_{2} \mathrm{O}_{3}$ & 3.06 & 2.54 & 3.09 & 3.45 & 8.07 & 8.22 & 7.96 & 5.73 & 3.12 & 4.75 & 8.07 \\
\hline & & Maghemite & $\mathrm{Fe}_{2} \mathrm{O}_{3}$ & $<-5.0$ & $<-5.0$ & $<-5.0$ & $<-5.0$ & -1.91 & -1.73 & -2.17 & -4.30 & $<-5.0$ & $<-5.0$ & -1.85 \\
\hline & & Magnetite & $\mathrm{Fe}_{3} \mathrm{O}_{4}$ & -2.41 & -3.14 & -2.63 & -2.03 & 5.34 & 5.79 & 5.48 & 2.65 & -2.17 & -0.60 & 5.70 \\
\hline & & Jarosite & $(\mathrm{K}, \mathrm{Na}, \mathrm{H}) \mathrm{Fe}_{3}\left(\mathrm{SO}_{4}\right)_{2}(\mathrm{OH})_{6}$ & $<-5.0$ & $<-5.0$ & $<-5.0$ & $<-5.0$ & -4.38 & -4.70 & $<-5.0$ & $<-5.0$ & $<-5.0$ & -4.20 & $<-5.0$ \\
\hline & & Siderite & $\mathrm{FeCO}_{3}$ & $<-5.0$ & $<-5.0$ & $<-5.0$ & $<-5.0$ & $<-5.0$ & $<-5.0$ & $<-5.0$ & $<-5.0$ & $<-5.0$ & $<-5.0$ & $<-5.0$ \\
\hline & \multirow[t]{2}{*}{$\mathrm{Pb}$} & Anglesite & $\mathrm{PbSO}_{4}$ & -0.39 & -0.28 & -0.28 & -0.49 & -0.90 & -0.95 & -1.01 & -1.0 & -0.59 & -0.74 & -0.97 \\
\hline & & Cerussite & $\mathrm{PbCO}_{3}$ & $<-5.0$ & $<-5.0$ & $<-5.0$ & $<-5.0$ & $<-5.0$ & $<-5.0$ & $<-5.0$ & $<-5.0$ & $<-5.0$ & $<-5.0$ & $<-5.0$ \\
\hline & \multirow[t]{3}{*}{$\mathrm{Zn}$} & Zincite & $\mathrm{ZnO}$ & $<-5.0$ & $<-5.0$ & $<-5.0$ & $<5.0$ & $<-5.0$ & $<-5.0$ & $<-5.0$ & $<-5.0$ & $<-5.0$ & $<-5.0$ & $<-5.0$ \\
\hline & & Willemite & $\mathrm{Zn}_{2} \mathrm{SiO}_{4}$ & $<-5.0$ & $<-5.0$ & $<-5.0$ & $<-5.0$ & $<5.0$ & $<-5.0$ & $<-5.0$ & $<-5.0$ & $<-5.0$ & $<-5.0$ & $<-5.0$ \\
\hline & & Smithsonite & $\mathrm{ZnCO}_{3}$ & $<-5.0$ & $<-5.0$ & $<-5.0$ & $<-5.0$ & $<-5.0$ & $<-5.0$ & $<-5.0$ & $<-5.0$ & $<-5.0$ & $<-5.0$ & $<-5.0$ \\
\hline \multirow{17}{*}{ 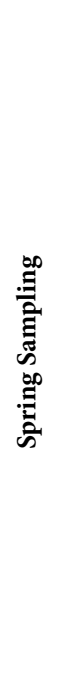 } & $\mathrm{Cd}$ & Otavite & $\mathrm{CdCO}_{3}$ & $<-5.0$ & $<-5.0$ & $<-5.0$ & $<-5.0$ & -0.81 & -0.18 & 0.01 & -0.35 & $<-5.0$ & $<-5.0$ & $<-5.0$ \\
\hline & \multirow[t]{5}{*}{$\mathrm{Cu}$} & Cuprousferrite & $\mathrm{CuFeO}_{2}$ & 1.36 & 0.34 & 0.91 & 0.48 & 10.05 & 15.28 & 15.19 & 15.92 & 0.57 & 1.14 & 3.10 \\
\hline & & Cupricferrite & $\mathrm{CuFe}_{2} \mathrm{O}_{4}$ & $<-5.0$ & $<-5.0$ & -4.91 & -4.76 & 15.40 & 13.98 & 18.47 & 20.20 & $<-5.0$ & $<-5.0$ & -2.65 \\
\hline & & Tenorite & $\mathrm{CuO}$ & $<-5.0$ & $<-5.0$ & $<-5.0$ & $<-5.0$ & -1.73 & -0.38 & -0.18 & -0.09 & $<-5.0$ & $<-5.0$ & $<-5.0$ \\
\hline & & Malachite & $\mathrm{Cu}_{2}\left(\mathrm{CO}_{3}\right)(\mathrm{OH})_{2}$ & $<-5.0$ & $<-5.0$ & $<-5.0$ & $<-5.0$ & -1.91 & -0.09 & 0.08 & 0.15 & $<-5.0$ & $<-5.0$ & $<-5.0$ \\
\hline & & Azurite & $\mathrm{Cu}_{3}\left(\mathrm{CO}_{3}\right)_{2}(\mathrm{OH})_{2}$ & $<-5.0$ & $<-5.0$ & $<-5.0$ & $<-5.0$ & -3.18 & -0.90 & -0.75 & -0.67 & $<-5.0$ & $<-5.0$ & $<-5.0$ \\
\hline & \multirow[t]{6}{*}{$\mathrm{Fe}$} & Goethite & $\mathrm{FeOOH}$ & 0.83 & 0.31 & 1.30 & 1.47 & 8.68 & 7.30 & 9.44 & 9.10 & -2.81 & -4.56 & 1.99 \\
\hline & & Hematite & $\mathrm{Fe}_{2} \mathrm{O}_{3}$ & 3.65 & 2.61 & 4.6 & 4.94 & 19.37 & 16.60 & 20.89 & 20.20 & -3.61 & $<-5.0$ & 5.99 \\
\hline & & Maghemite & $\mathrm{Fe}_{2} \mathrm{O}_{3}$ & $<-5.0$ & $<-5.0$ & $<-5.0$ & $<-5.0$ & 9.12 & 6.32 & 10.57 & 9.81 & -14.00 & $<-5.0$ & -4.26 \\
\hline & & Magnetite & $\mathrm{Fe}_{3} \mathrm{O}_{4}$ & -2.13 & -3.61 & -1.31 & -1.14 & 17.07 & 18.20 & 22.37 & 22.22 & -9.32 & $<-5.0$ & 1.41 \\
\hline & & Jarosite & $(\mathrm{K}, \mathrm{Na}, \mathrm{H}) \mathrm{Fe}_{3}\left(\mathrm{SO}_{4}\right)_{2}(\mathrm{OH})_{6}$ & $<-5.0$ & $<-5.0$ & -4.71 & -4.99 & 6.29 & -0.68 & 5.07 & 4.30 & $<-5.0$ & $<-5.0$ & -4.99 \\
\hline & & Siderite & $\mathrm{FeCO}_{3}$ & $<-5.0$ & $<-5.0$ & $<-5.0$ & $<-5.0$ & -2.50 & 0.50 & -0.01 & 0.58 & $<-5.0$ & $<-5.0$ & $<-5.0$ \\
\hline & \multirow[t]{2}{*}{$\mathrm{Pb}$} & Anglesite & $\mathrm{PbSO}_{4}$ & -0.67 & -0.55 & -0.60 & -0.88 & -2.18 & -2.40 & -2.72 & -2.33 & -1.76 & -1.16 & -0.99 \\
\hline & & Cerussite & $\mathrm{PbCO}_{3}$ & $<-5.0$ & $<-5.0$ & $<-5.0$ & $<-5.0$ & -1.46 & -0.90 & -1.04 & -0.96 & $<-5.0$ & $<-5.0$ & $<-5.0$ \\
\hline & \multirow[t]{3}{*}{$\mathrm{Zn}$} & Zincite & $\mathrm{ZnO}$ & $<-5.0$ & $<-5.0$ & $<-5.0$ & $<-5.0$ & -2.69 & -1.17 & -0.74 & -0.96 & $<-5.0$ & $<-5.0$ & $<-5.0$ \\
\hline & & Willemite & $\mathrm{Zn}_{2} \mathrm{SiO}_{4}$ & $<-5.0$ & $<-5.0$ & $<-5.0$ & $<-5.0$ & -1.72 & 1.30 & 2.12 & 1.65 & $<-5.0$ & $<-5.0$ & $<-5.0$ \\
\hline & & Smithsonite & $\mathrm{ZnCO}_{3}$ & $<-5.0$ & $<5.0$ & $<-5.0$ & $<-5.0$ & -0.39 & 0.24 & 0.42 & 0.10 & $<-5.0$ & $<-5.0$ & $<-5.0$ \\
\hline
\end{tabular}


Table 2 (cont.). Saturation indices of reactive phases of $\mathrm{Cd}, \mathrm{Cu}, \mathrm{Fe}, \mathrm{Pb}$ and $\mathrm{Zn}$ of AMD from the Xochula Stream of Taxco, Guerrero, Mexico.

\begin{tabular}{|c|c|c|c|c|c|c|c|c|c|c|c|c|c|c|}
\hline & Element & Mineral & Formula & XO-01 & XO-03 & XO-06 & XO-08 & XO-10 & XO-11 & XO-12 & XO-14 & XO-15 & XO-16 & XO-17 \\
\hline \multirow{11}{*}{ 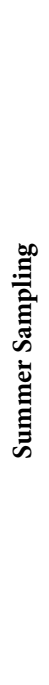 } & \multirow[t]{4}{*}{$\mathrm{Cu}$} & Cuprousferrite & $\mathrm{CuFeO}_{2}$ & 0.62 & 0.77 & 1.70 & 1.74 & 11.40 & 12.04 & 11.81 & 12.49 & 14.76 & 3.18 & 3.85 \\
\hline & & Tenorite & $\mathrm{CuO}$ & $<-5.0$ & $<-5.0$ & $<-5.0$ & $<-5.0$ & -2.09 & -1.74 & -1.89 & -1.52 & -0.46 & $<-5.0$ & $<-5.0$ \\
\hline & & Malachite & $\mathrm{Cu}_{2}\left(\mathrm{CO}_{3}\right)(\mathrm{OH})_{2}$ & $<-5.0$ & $<-5.0$ & $<-5.0$ & $<-5.0$ & $<-5.0$ & $<-5.0$ & $<-5.0$ & $<-5.0$ & $<-5.0$ & $<-5.0$ & $<-5.0$ \\
\hline & & Azurite & $\mathrm{Cu}_{3}\left(\mathrm{CO}_{3}\right)_{2}(\mathrm{OH})_{2}$ & $<-5.0$ & $<-5.0$ & $<-5.0$ & $<-5.0$ & $<-5.0$ & $<-5.0$ & $<-5.0$ & $<-5.0$ & $<-5.0$ & $<-5.0$ & $<-5.0$ \\
\hline & \multirow{5}{*}{$\mathrm{Fe}$} & Hematite & $\mathrm{Fe}_{2} \mathrm{O}_{3}$ & 3.04 & 4.29 & 6.90 & 7.09 & 12.49 & 12.53 & 13.30 & 13.72 & 17.39 & -1.47 & 6.03 \\
\hline & & Maghemite & $\mathrm{Fe}_{2} \mathrm{O}_{3}$ & $<-5.0$ & $<-5.0$ & -3.34 & -3.38 & 2.13 & 2.20 & 2.90 & 3.33 & 7.00 & $<-5.0$ & -4.03 \\
\hline & & Magnetite & $\mathrm{Fe}_{3} \mathrm{O}_{4}$ & -3.11 & -1.67 & 1.38 & 1.77 & 11.96 & 12.28 & 13.01 & 13.75 & 18.63 & $<-5.0$ & 1.54 \\
\hline & & Jarosite & $(\mathrm{K}, \mathrm{Na}, \mathrm{H}) \mathrm{Fe}_{3}\left(\mathrm{SO}_{4}\right)_{2}(\mathrm{OH})_{6}$ & ${ }_{6}<-5.0$ & -4.07 & -0.89 & -1.97 & -2.22 & -3.36 & -1.49 & -1.38 & 2.07 & $<-5.0$ & -4.82 \\
\hline & & Siderite & $\mathrm{FeCO}_{3}$ & $<-5.0$ & $<-5.0$ & $<-5.0$ & $<-5.0$ & $<-5.0$ & $<5.0$ & $<-5.0$ & $<-5.0$ & $<-5.0$ & $<-5.0$ & $<-5.0$ \\
\hline & $\mathrm{Pb}$ & Anglesite & $\mathrm{PbSO}_{4}$ & -0.79 & -0.86 & -0.63 & -1.25 & -1.64 & -1.82 & -1.71 & -1.59 & -1.36 & -1.32 & -0.94 \\
\hline & $\mathrm{Zn}$ & Smithsonite & $\mathrm{ZnCO}_{3}$ & $<-5.0$ & $<-5.0$ & $<-5.0$ & $<-5.0$ & $<-5.0$ & $<-5.0$ & $<-5.0$ & $<-5.0$ & $<-5.0$ & $<-5.0$ & $<-5.0$ \\
\hline
\end{tabular}

We stated before that passage of AMD of the Xochula stream through a culvert made of concrete produces a significant rise of $\mathrm{pH}$ in all the seasons and that this neutralization event entails the most significant chemical change in the water of the stream. The role of bedrock in the neutralization or their influence in the chemistry of water is not obvious, i.e. no significant change in the chemistry of AMD was recorded. Although samples from all the sampling seasons could provide insights on this issue, samples from the fall sampling season are more suitable since they only experienced one major chemical change between the sampling points $\mathrm{XO}-06$ and $\mathrm{XO}-08$ (Figure 5). Samples collected before this major chemical breaking point (XO-01, $\mathrm{XO}-03$ and XO-06), do not show significant differences in $\mathrm{pH}$ or metal (total and soluble) contents between themselves or do samples XO-10 to XO-17 collected after the chemical breaking point (Table S1). This fact suggests that bedrock plays a limited role in the neutralization of AMD in the zone despite its calcareous nature and its proven buffer capacity (Romero et al., 2011). This apparent low capacity of bedrock for neutralizing acidic waters is in part motivated by the high flow rate of the Xochula stream, which reduces the time of interaction of water with bedrock as well as by the formation of coatings over bedrock produced by the precipitation of Fe-oxihydroxides, which also reduces the interaction of acidic waters with bedrock. Nevertheless, the $\mathrm{Pb}$ isotopic compositions reveal that at least two samples (XO-16 and XO-17) collected near the Xochula stream mouth with the Taxco River and one tributary (XO-05) have a more radiogenic isotopic composition relative to the other analyzed samples. This indicates the intervention of a more radiogenic source represented most likely by rocks of the Morelos or Taxco Schist formations, which have the most radiogenic $\mathrm{Pb}$ isotopic compositions recorded in the zone (Talavera et al., 2016; Vázquez-Bahena et al., 2017). This fact indicates that bedrock already intervenes in the composition of water in the Xochula stream even though intervention is not so evident.

Neutralization of AMD by mixing with freshwater is a common and efficient process in nature but unfortunately it is not well documented (e.g. Henry et al., 1999; Christensen, 2005). In the zone, freshwater from tributaries is mixed with AMD in at least three points of the stream (labeled 1, 2 and 3 in Figure 2). Chemical variations recorded at these sites offer a unique opportunity to evaluate whether the mix- ing of AMD with freshwater is a significant neutralizing process in the Xochula stream and if it plays a role in the chemistry of water. At site 1, sample XO-01 is AMD before mixing with freshwater. Samples $\mathrm{XO}-02$ and $\mathrm{XO}-03$ are AMD after mixing. At site 2, the sample XO-03 is AMD before mixing with freshwater, finally $\mathrm{XO}-05$ and $\mathrm{XO}-06$ are AMD after the Guerrero mine. Sites 1 and 2 are located before AMD reaches the duct of concrete, where it records the most acidic conditions. At these two sites, chemical changes after mixing AMD with freshwater are overall minimal and not significant for all the sampling seasons (Table S1) despite the high $\mathrm{pH}$ of water from tributaries $\mathrm{XO}-02$ (6.70-7.37) and XO-05 (7.52-7.95). This is probable due to the low flow of freshwater mixing with a largely higher flow of AMD. It was observed that water from tributaries XO-02 and XO-05 disappear during the winter season. Site 3 (Figure 2), is in the less acidic segment of the Xochula stream and underwent significant chemical changes in contrast to sites 1 and 2. Samples of this site are XO-08 (AMD before mixing with freshwater) and $\mathrm{XO}-09$ and XO-10 (AMD after mixing). It is noteworthy that during the winter, spring and summer seasons, between these two points, the $\mathrm{pH}$ increased and, in all seasons, the Ca content raised and the contents of soluble and total trace elements decreased suggesting that at higher $\mathrm{pH}, \mathrm{AMD}$-freshwater mixing has a more relevant effect in the neutralization process.

Besides the evidence given by the $\mathrm{Pb}$ isotope composition on the participation of bedrock in the chemistry of AMD, particularly in the samples (XO-16 and XO-17) collected close to the mouth of the Xochula stream and the tributary XO-05 discussed above, the $\mathrm{Pb}$ isotopic composition also provides information on the source(s) of metals contained in AMD. Except these three samples (XO-05, XO-16 and $\mathrm{XO}-17$ ), the remainder match the $\mathrm{Pb}$ isotopic composition of hypogene (galena, pyrite, sphalerite ) phases from the Taxco ore deposit, derivative tailings and contaminated soils (Cummings, 1979; Vázquez-Bahena et al., 2017) pointing to ores as the most probable source of metals from AMD. The $\mathrm{Pb}$ isotopic composition of the three more radiogenic samples (XO-05, XO-16 and XO-17) indicates that $\mathrm{Pb}$ and associated metals also derive from the Taxco ores but having influence of a more radiogenic source represented likely by rocks from the Morelos and/or Taxco Schist formations (Figure 3). 


\section{CONCLUSIONS}

Acidic waters are pumped from flooded mines to the Xochula stream, a tributary of the Taxco River in the mining region of Taxco, Guerrero producing the only known occurrence of AMD in the zone.

AMD is characterized by low $(<3.0) \mathrm{pH}$, high sulfate and high concentrations of metals and As, and shows significant spatial (along the stream) and less evident temporal (seasonal) chemical variations.

Passage of AMD through a culvert made of concrete causes neutralization, which induced the most important chemical change recorded in the AMD in all the seasons decreasing the EC and the concentration of soluble and total trace metals.

Partitioning of metals and As between dissolved and particulate phases is clearly controlled by $\mathrm{pH}$ for $\mathrm{Al}, \mathrm{Cu}, \mathrm{Fe}$ and $\mathrm{Pb}$, but its influence in the control $\mathrm{Mn}, \mathrm{Zn}$ and $\mathrm{Cd}$ is less evident.

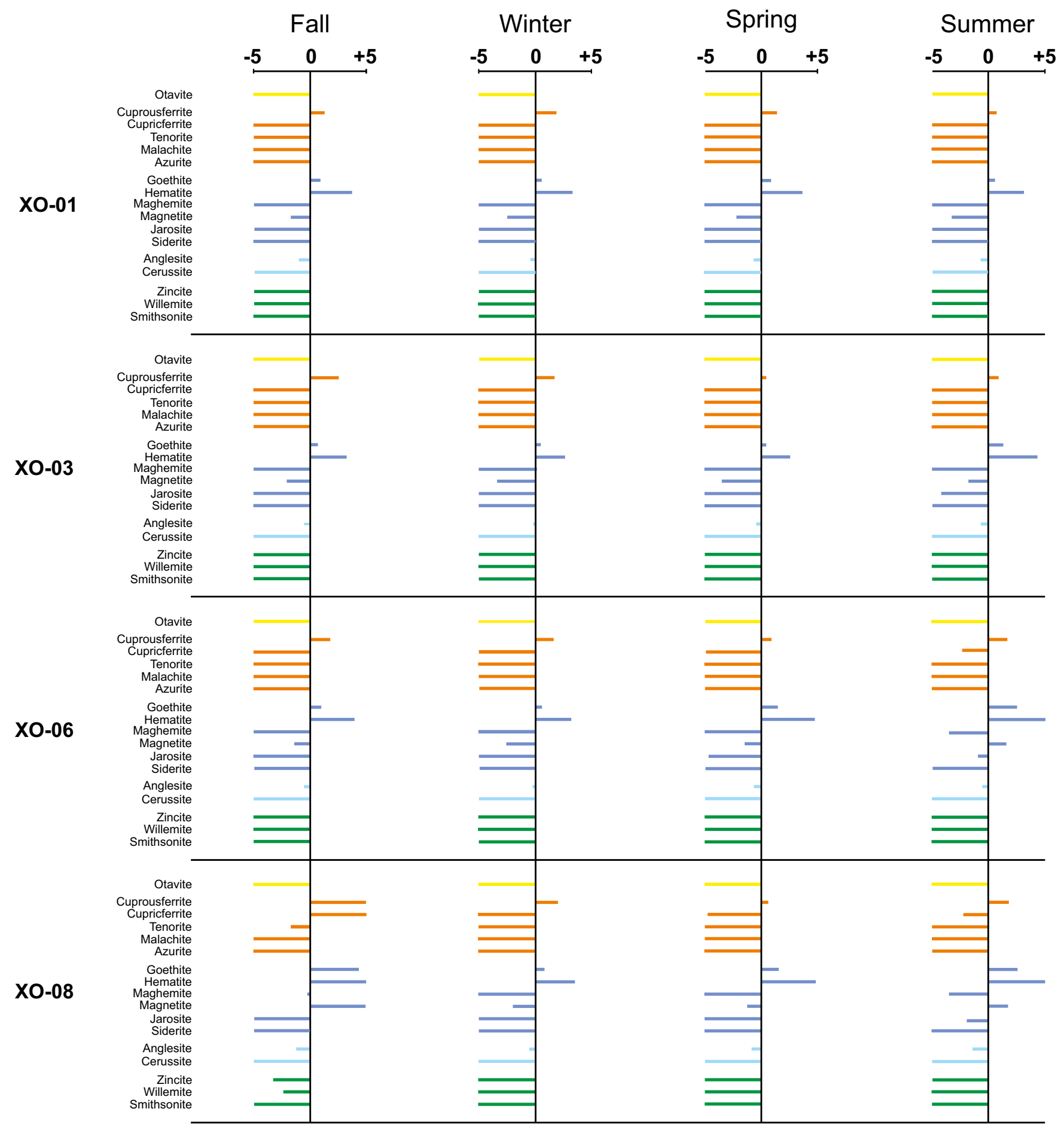

Figure 6. Hydrogeochemical speciation of AMD samples from the Xochula Stream in Taxco Guerrero, Mexico. X-axis represents the saturation index (continues). 


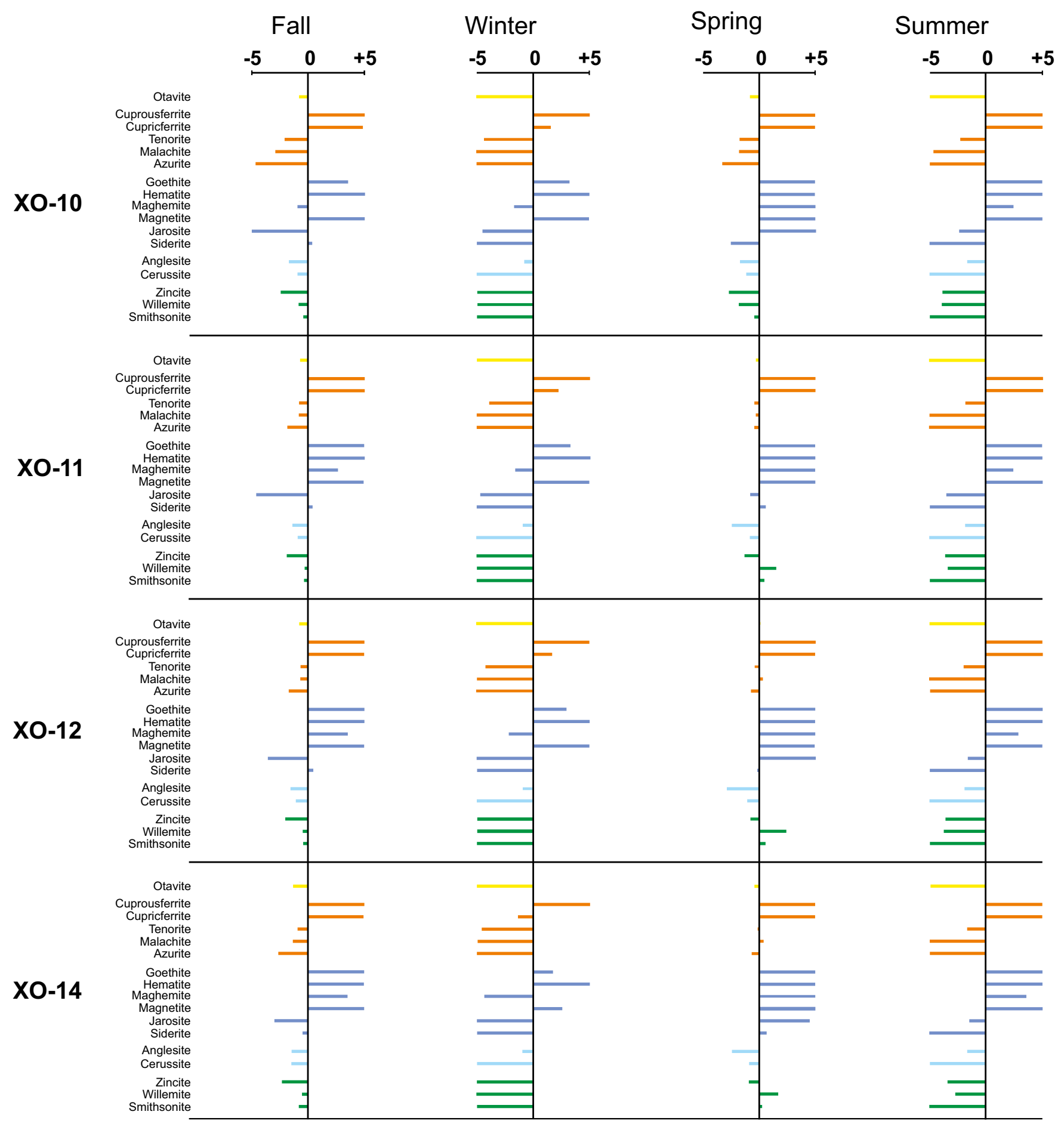

Figure 6 (cont.). Hydrogeochemical speciation of AMD samples from the Xochula Stream in Taxco Guerrero, Mexico. X-axis represents the saturation index (continues).

The role of bedrock in the neutralization of AMD of the Xochula stream is insignificant in spite of its calcareous nature and its buffer capacity. This behavior is likely influenced by the short interaction time between AMD and bedrock and by the formation of coatings.

Mixing of AMD with freshwater is only a significant neutralizing process in the less acidic segment of the stream.

Neutralization of AMD entails a reduction of the concentration of trace metals. Concentration of As seems to be controlled by its adsorption onto $\mathrm{Fe}$ and $\mathrm{Mn}$ oxyhydroxides and otavite is the main reactive phase controlling $\mathrm{Cd}$ concentrations. Copper is controlled by the precipitation of cuprousferrite and cupricferrite, although tenorite, malachite and azurite are significant reactive phases in the less acidic samples. Iron is controlled by the precipitation of goethite, hematite, maghemite, magnetite and, to a lesser extent, by jarosite and siderite. Adsorption processes mainly control lead although, anglesite is a reactive phase in highly acidic and cerussite in less acidic samples. 


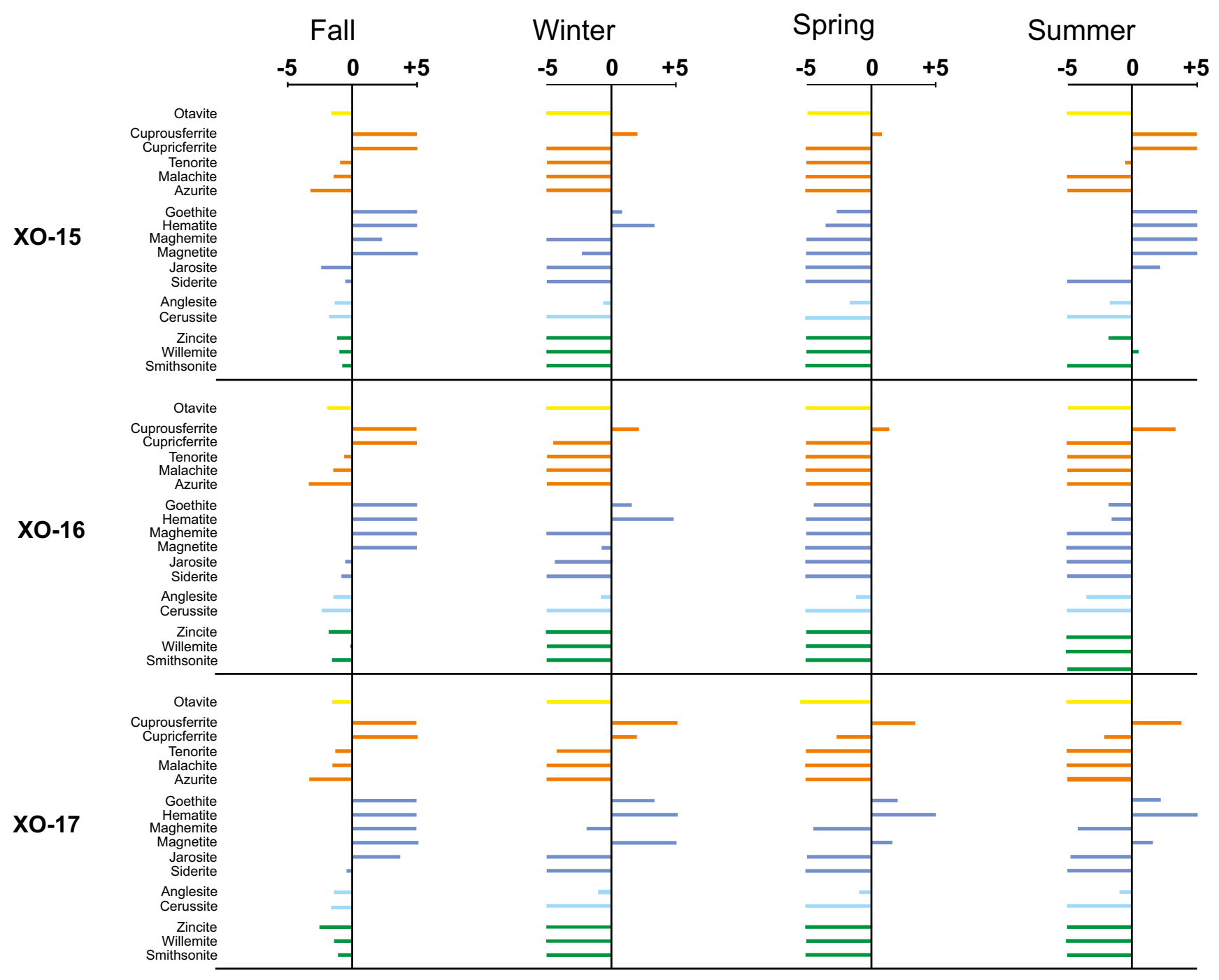

Figure 6 (cont.). Hydrogeochemical speciation of AMD samples from the Xochula Stream in Taxco Guerrero, Mexico. X-axis represents the saturation index.

Finally, zincite, willemite and smithsonite control the precipitation of $\mathrm{Zn}$.

The $\mathrm{Pb}$ isotopic composition indicates that metals contained in the AMD derive from the Taxco ores but that influence of lithogenic $\mathrm{Pb}$ derived mainly of the most radiogenic rock of the Morelos and Taxco Schist formations is non negligible.

\section{SUPPLEMENTARY MATERIAL}

Table S1 can be found in the table of contents of this issue.

\section{ACKNOWLEDGEMENTS}

This contribution formed part of a PhD thesis by NMQC. Authors are very grateful to Mark Baker, manager of the Laboratory of Geochemistry of the Department of Geosciences, University of Arizona for valuable support during acquisition of $\mathrm{Pb}$ isotopic analysis. Comments and suggestions by three anonymous reviewers greatly help to improve the manuscript. Authors thank Travis Ashworth for reviewing the English version of the paper.

\section{REFERENCES}

Affandi, F.N.A., Kusin, F.M., Sulong, N.A., Madzin, Z., 2018, Hydrogeochemical assessment of mine-impacted water and sediment of iron ore mining. IOP Conf. Series: Earth and Environmental Science 140012023 , doi:10.1088/1755-1315/140/1/012023

Akcil, A., Koldas, S., 2006, Acid mine drainage (AMD): causes, treatment and case studies: Journal of Cleaner Production, 14, 1139-1145.

Armienta, M.A., Talavera, O., Morton, O., Barrera, M., 2003, Geochemistry of metals from mine tailings in Taxco, Mexico: Bulletin of Environmental Contamination and Toxicology, 71, 387-393.

Ball, J.W., Nordstrom, D.K., 1991, User's Manual for WATEQ4F, with Revised Thermodynamic Data Base and Test Cases for Calculating Speciation of Major, Trace, and Redox Elements in Natural Waters: U.S. Geological Survey, Open-File Report 91-183, Washington DC, 189 pp.

Battaglia M., Hose, G.C., Turak, E., Warden, B., 2005, Depauperate macroinvertebrates in a mine affected stream: clean water may be the key to recovery: Environmental Pollution, 138, 132-141.

Campa, M.F., Ramírez, J., 1979, La evolución geológica y la metalogénesis del noroccidente de Guerrero: Serie Técnico-Científica, 1: Universidad Autónoma de Guerrero, $101 \mathrm{pp}$.

Campa-Uranga, M.F., Torres de León, R., Iriondo, A., Premo, W.R., 2012, Caracterización geológica de los ensambles metamórficos de Taxco y Taxco el Viejo, Guerrero, México: Boletín de la Sociedad Geológica Mexicana, 64, 369-385. 
Campaner, V., Luiz-Silva, W., Machado, W., 2014, Geochemistry of acid mine drainage from a coal mining area and processes controlling metal attenuation in stream waters, southern Brazil: Anais da Academia Brasileira de Ciências, 86, 539-554.

Chapman, B.M., Jones, D.R., Jung, R.F., 1983, Processes controlling metal ion attenuation in acid mine drainage streams: Geochimica et Cosmochimica Acta, 47, 1957-1973.

Chon, H-T., Hwang, J-H., 2000, Geochemical characteristics of the acid mine drainage in the water system in the vicinity of the Dogye Coal Mine in Korea: Environmental Geochemistry and Health, 22, 155-172.

Cole, J., 2004, Arsenic in a Village Drinking Water Supply: University of Calgary, Canada, Mexico, Master Thesis, 60pp.

Christensen, E.D., 2005, Assessment, water-quality trends, and options for remediation of acidic drainage from abandoned coal mines near Huntsville, Missouri, 2003-2004: U.S. Geological Survey Scientific Investigations Report, 2005-5202, 84 pp.

Cummings, G.L., 1979, Isotopic composition of lead in Mexican mineral deposits: Economic Geology, 74, 1395e1407

DeNicol, D.M., Stapleton, M.G., 2002, Impact of acid mine drainage on benthic communities in strems: the relative roles of substratum $v s$. aqueous effects: Environmental Pollution, 119, 303-315.

Embile Jr., R., Walder, I., Madai, F., Móricz, F., Rzepka, P., Walder, P., 2016 Grain Size Effects on Mine Water Quality and Acid/Neutral Rock Drainage Production in Kinetic Testing Using Recsk Porphyry Skarn Cu-Zn Deposit Rocks: Mine Water and the Environment, 35, 421-434.

Farfán-Panamá, J.L., Camprubi, A., González-Partida, E., Iriondo, A., GonzalezTorres, E., 2015, Geochronology of Mexican mineral deposits. III: the Taxco epithermal deposits, Guerrero: Boletín de la Sociedad Geológica Mexicana, 67, 357-366.

Florence, K., Sapsford, D.J., Johnson, D.B., Kay, C.M., Wolkersdorfer, C., 2016, Iron-mineral accretion from acid mine drainage and its application in passive treatment: Environmental Technology, 37, 1428-1440, DOI $10.1080 / 09593330.2015 .1118558$

Galer, S.J.G., Abouchami, W., 1998, Practical application of lead triple spiking for correction of instrumental mass discrimination: Mineralogical Magazine, 62, 491-492.

Gómez-Bernal, J.M., Santana-Carrillo, J., Romero-Martín, F., ArmientaHernández, M.A., Morton-Bermea, O., Ruiz-Huerta, E.A., 2010, Plantas de sitios contaminados con desechos mineros en Taxco, Guerrero. México: Boletín de la Sociedad Botánica Mexicana, 87, 131-133.

Gray, D.P., Harding, J.S., Lindsay, P., 2016, Remediation of a major acid mine drainage point source discharge restores headwater connectivity for a diadromous native fish: New Zealand Journal of Marine and Freshwater Research, 50, 566-580.

Henry, T.B., Irwin, E.I., Grizzle, J.M., Wildhaber, M.L., Brumbaugh, W.G., 1999, Acute Toxicity of an Acid Mine Drainage Mixing Zone to Juvenile Bluegill and Largemouth Bass: American Fisheries Society, 128, 919-928.

Jambor, J.L., 2003, Mine-waste mineralogy and mineralogical perspectives of acid-base accounting, in Jambor, J.L, Blowes, D.W., Ritchie, A.I.M. (eds.) Environmental aspects of mine wastes: Mineralogical Association of Canada Short Course Series 31, 17-146.

Lachmar, T.E., McDonough, H.L., Burk, N.I., Kolesar, P., Doucette, W., 2019, Effect of ore mineralogy and bedrock lithology on metal loading rates and acid-mine drainage: Bayhorse Creek, Idaho and the North Fork of the American Fork River, Utah: Mine Water and the Environment, https:// doi.org/10.1007/s10230-018-00574-1

Lakovleva, E., Mäkila, E., Salonen, J., Sitarz, M., Wang, S., Sillnpää, M., 2015, Acid mine drainage (AMD) treatment: Neutralization and toxic elements removal with unmodified and modified limestone: Ecological Engineering, $81,30-40$.

Lee, G., Bigham, J.M., Faure, G., 2002, Removal of trace metals by coprecipitation with $\mathrm{Fe}, \mathrm{Al}$ and $\mathrm{Mn}$ from natural waters contaminated with acid mine drainage in the Ducktown Mining District, Tennessee: Applied Geochemistry, 17, 569-581.

Makarov, V.N., Korytnaya, O.P., Lugovskaya, A.S., Vasileva, T,N., Makarov, D.V., 2003, Effect of particle size on solubility and neutralizing ability of carbonate minerals: Chemistry for Sustainable Development, 11, 621-626.

Martínez, T., Lartigue, J., Juarez, F., Avila-Perez, P., Zarazua, G., Marquez, C., Alvarez, V., 2004, Application of lead isotopic ratios in atmospheric pollution studies in the Valley of México: Journal of Atmospheric Chemistry, 49, 415-424.

Moreno, M.E., Acosta-Saavedra, L.C., Meza-Figueroa, D., Vera, E., Cebrian, M.E., Ostrosky-Wegman, P., Calderon-Aranda, E.S., 2010, Biomonitoring of metal in children living in a mine tailings zone in Southern Mexico: a pilot study: International Journal of Hygiene and Environmental Health, 213, 252-258.

Morton-Bermea, O., Rodríguez-Salazar, M.T., Hernández-Alvarez, E., GarcíaArreola, M.E., Lozano-Santacruz, R., 2011, Lead isotopes as tracers of anthropogenic pollution in urban topsoils of Mexico City: Chemie ErdeGeochemistry, 71, 189-195.

Mukherjee, S., 2011, Environmental Minearlogy, in Applied Mineralogy: Applications in industry and Environment: Dordrecht, Holland, Springer, 490-525.

Ngole-Jeme, V.M., Fantke, P., 2017, Ecological and human health risks associated with abandoned gold mine tailings contaminated soil: Plos One, 12, e0172517, DOI: 10.1371/journal.pone.0172517

NOM-001-SEMARNAT-1996 (Norma Oficial Mexicana, SEMARNAT), 1997, Que establece los límites permisibles de contaminantes en las descargas de aguas residuales en aguas y bienes nacionales: México, Secretaría del Medio Ambiente y Recursos Naturales.

Hogsden, K.L., Harding, J.S., 2012, Consequences of acid mine drainage for the structure and function of benthic stream communities: a review: Freshwater Science, 31, 108-120, https://doi.org/10.1899/11-091.1

Johnson D.B., Hallberg, K.B, 2005, Acid mine drainage remediation options: a review: Science of the Total Environment, 338, 3-14.

Parkhurst, D.L., 1995, User's guide to PHREEQC-A computer program for speciation, reaction-path, advective-transport, and inverse geochemical calculations: U.S. Geological Survey Water-Resources Investigations Report 95-4227, 143 pp.

Romero, F.M., Armienta, M.A., González-Hernández, G., 2007, Solid-phase control on the mobility of potentially toxic elements in an abandoned lead/ zinc mine tailings impoundment: Applied Geochemistry, 22, 109e127.

Romero, F.M., Núñez, L., Gutiérrez, M.E., Armienta, M.A., Ceniceros-Gómez, A.E., 2011, Evaluation of the Potential of Indigenous Calcareous Shale for Neutralization and Removal of Arsenic and Heavy Metals From Acid Mine Drainage in the Taxco Mining Area, Mexico: Archives of Environmental Contamination and Toxicology, 60, 191-203.

Ruiz-Huerta, E., Armienta-Hernández, M.A., 2012, Acumulación de arsénico y metales pesados en maíz en suelos cercanos a jales o residuos mineros: Revista Internacional de Contaminación Ambiental, 28, 103-117, 28, 103-117.

Sánchez-España, J., López-Pamo, E., Santofimia-Pastor, E., Reyes-Andrés, J., Martín-Rubí, J.A., 2006, The Removal of Dissolved Metals by Hydroxysulphate Precipitates during Oxidation and Neutralization of Acid Mine Waters, Iberian Pyrite Belt: Aquatic Geochemistry, 12, 269-298, DOI 10.1007/s10498-005-6246-7

Skousen, J., Zipper, C.E., Rose, A., Ziemkiewicz, P.F., Nairn, R., McDonald, L.M., Kleinmann, R.L., 2017, Review of Passive Systems for Acid Mine Drainage Treatment: Mine Water and the Environment, 36, 133-153.

Soto-Ríos, M.L., Juárez-Pérez, C.A., Rendón-Gandarilla, F.J., Talavera-Mendoza, O., Aguilar-Madrid, G., 2017, Elevated Blood Lead Levels in Children Associated with Living near Mining Waste Sites in Guerrero/Mexico: Environments, 4, 41, doi.org/10.3390/environments4020041

Talavera, M.O., Yta, M., Moreno Tovar, R., Dótor-Almazán, A., Flores-Mundo, N., Duarte Gutiérrez, C., 2005, Mineralogy and geochemistry of sulfidebearing tailings from silver mines in the Taxco, Mexico area to evaluate their potential environmental impact: Geofísica Internacional, 44, 49e64.

Talavera, M.O., Armienta Hernández, M.A., García-Abundis, J., Flores-Mundo, N., 2006, Hydrogeochemistry of leachates from el fraile sulfide tailings Piles in Taxco, Guerrero, southern Mexico: Environmental Geochemistry and Health, 28, 243e265.

Talavera, M.O., Ruiz, J., Díaz-Villaseñor, E., Ramírez-Guzmán, A., Cortés, A., Salgado-Souto, S.A., Dótor-Almazán, A., Rivera-Bustos, R., 2016. Water-rock-tailings interactions and sources of sulfur and metals in the subtropical mining region of Taxco, Guerrero (southern Mexico): a multiisotopic approach: Applied Geochemistry, 66, 73-81.

Talukdar, B., Kalita, H.K., Basumatary, S., Saikia, D.J., Sarma, D., 2017, Cytotoxic and genotoxic effects of acid mine drainage on fish Channa punctata 
(Bloch): Ecotoxicology and Environmental Safety, 144, 72-78, DOI: 10.1016/j.ecoenv.2017.06.007

Thibodeau, A.M., Habicht-Mauche, J., Huntley, D.L., Chesley, J.T., Ruiz, J., 2013, High precision isotopic analyses of lead ores from New Mexico by MC-ICP-MS: implications for tracing the production and exchange of Pueblo Viejo IV glaze-decored pottery: Journal of Archaeology Science, 40, 3067e3075.

Vázquez-Bahena, A.B., Talavera-Mendoza, O., Moreno-Godínez, M.E., SalgadoSouto, S.A., Ruiz, J., Huerta-Beristain, G., 2017, Source apportionment of lead in the blood ofwomen of reproductive age living near tailings in Taxco, Guerrero, Mexico: An isotopic study: Science of the Total Environment, $583,104-114$.

Watten, B.J., Sibrell, P.L., Schwartz, M.F., 2005, Acid neutralization within limestone sand reactors receiving coal mine drainage: Environmental Pollution, 137, 295-304.

Webb, J.A., Sasowsky, D., 1994, The interaction of acid mine drainage with a carbonate terrane: evidence from the Obey River, north-central Tennessee: Journal of Hydrology, 161, 327-346.

Wilkie, J.A. Hering, J.G., 1996, Adsortion of arsenic onto hydrous ferric oxide: effects of adsorbate/adsorbent ratios and co-occurring solutes: Colloids and Surfaces A: Physicichemical and Engineering aspects, 107, 97-110.

Williams, T.M., Smith, B., 2000, Hydrochemical characterization of acute acid mine drainage at Iron Duke Mine, Mazowe, Zimbabwe: Environmental Geology, 39, 272-278.
Wilmoth, R.C., 1974, Limestone and limestone-lime neutralization of acid mine drainage: USEPA Technological Series Repor, EPA-670/2-74-051.

Winterbourn, M.J., McDiffett, W.F., Eppley, S.J., 2000, Aluminium and iron burdens of aquatic biota in New Zealand streams contaminated by acid mine drainage: effects of trophic level: Science of the Total Environment, 254, 45-54.

Zhuang, P., Zou, B., Li, N.Y., Li, Z.A., 2009, Heavy metal contamination in soils and food crops around Dabaoshan mine in Guangdong, China: implication for human health: Environmental Geochemistry and Health, 31, 707-715.

Manuscript received: november 22, 2018

Corrected manuscript received: october 15, 2019

Manuscript accepted: october 16, 2019 